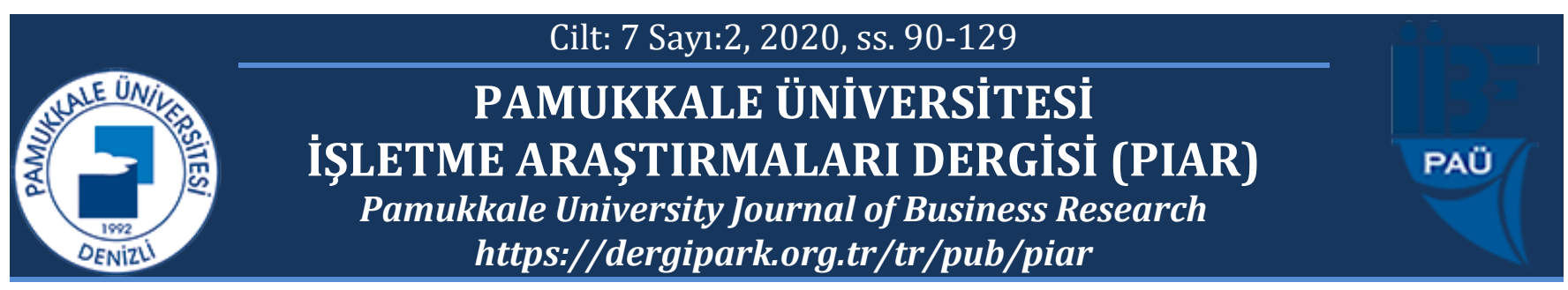

\title{
İş Tatmininin Örgütsel Bağlılık İle İşgören Performansı Arasındaki İlişkide Aracılık Rolü
}

\author{
The Mediator Role of Job Satisfaction on The Relationship Between \\ Organizational Commitment and Employee Performance
}

Ali ŞİMŞEK ${ }^{1}$

\section{Tahsin AKÇAKANAT ${ }^{3 *}$}

\footnotetext{
${ }^{1}$ Isparta Uygulamalı Bilimler Üniversitesi, Isparta MYO, Yönetim ve Organizasyon Bölümü, alisimsek@isparta.edu.tr, https://orcid.org/0000-0001-6066-7147

2Süleyman Demirel Üniversitesi, İ̈BF, İşletme Bölümü, nuriomurbek@sdu.edu.tr, https://orcid.org/0000-0002-03604040

33üleyman Demirel Üniversitesi, İ̈BF, İşletme Bölümü, tahsinakcakanat@sdu.edu.tr, https://orcid.org/0000-0001-94146868

*Yazışılan Yazar/Corresponding author
}

Makale Geliş/Received: 06.10.2020

Öz

Bu çalı̧manın amacı, örgütsel bağhllık ile işgören performansı arasındaki ilişkide, iş tatmininin aracılık rolünün belirlenmesidir. Çalı̧̧manın önemi, bu üç kavramla ilgili bir model önerilmesi ve bu modelin test edilmesidir. Çalışmada araştırma yöntemi nicel araştırma yöntemi ve araştırma türü ilişkisel (korelasyonel) olarak tercih edilmiştir. Veri toplama tekniği ise anket tekniğidir. Çalışmanın örneklemini, bir devlet üniversitesinde 2019-2020 eğitim öğretim yılinda çalışmakta olan 2793 idari personel oluşturmaktadır. İlgili personele 600 anket dağıttlmış, dağıtılan anketlerden 324 'ü yantlanmıs olarak geri toplanmıştır. Gerekli incelemeler sonucunda 324 anketten 280'i analiz için uygun görülmüştür. Bu çalışmada, duygusal bağlllık ile işgören performansı arasındaki ilişkide dışsal tatminin "tam aracilk rolünde" olduğu tespit edilmiştir. Devam bağlllı̆̆ ile işgören performansı arasindaki ilişkide ise içsel tatminin "kısmi aracllk rolünde" olduğu sonucu elde edilmiştir.

Anahtar kelimeler: İş Tatmini, Örgütsel Bağlllık, İşören Performansı, Üniversite, İdari Personel

JEL kodlart: J28, D23, M54, I23, J29
Makale Kabul/Accepted: 08.11.2020

\begin{abstract}
The aim of this study is to determine the mediating role of job satisfaction in the relationship between organizational commitment and employee performance. The importance of the study is that a model related to these three concepts is proposed and this model is tested. In the study, research method was chosen as quantitative research method and research type as correlational research. Data collection technique is the questionnaire technique. The sample of the study consists of 2793 administrative staff working at a state university in the 2019-2020 academic year. 600 questionnaires were distributed to the relevant personnel, and 324 of the distributed questionnaires were collected and answered. As a result of the necessary investigations, 280 out of 324 questionnaires were deemed suitable for analysis. In this study, it was determined that external satisfaction is in the "full mediating role" in the relationship between emotional commitment and employee performance. In the relationship between attendance commitment and employee performance, the result is that internal satisfaction is in the "partial intermediary role".
\end{abstract}

Keywords: Job Satisfaction, Organizational Commitment, Employee Performance, University, Administrative Staff

JEL codes: J28, D23, M54, I23, J29 


\section{GİRIŞ}

Örgütsel bağlılık konusu 1970'lerden sonra araştırmacıların çalışmalarında yaygın bir şekilde yer almaya başlamıştır (Gül, 2002: 37). Bu konudaki ilk araştırma 1956 yılında Whyte tarafından yapılmıştır. Örgütsel bağlılık konusunda katkı sunan araştırmacılardan bazıları Dubin, Lodahl, Kejner, Greenhaus, Mirels, Garrett, Greenhaus, Simon, Taveggia, Ziemba, Mowday, Steers ve Porter şeklindedir. Araştırmacılar tarafından bağlılık konusunda en sık kullanılan kavramlardan bazıları ise Protestan iş etiği, çalışmanın ve kurumun önemi, tecrübe, çalıştığı kurum ve örgütsel bağlılıktır (Marrow ve McElroy, 1986: 139).

Literatürde örgütsel bağlılıkla ilgili yapılmış birçok tanım bulunmaktadır. Bu konudaki en kapsamlı çalışmalardan birisini Marrow (1983), 25 araştırmacının tanımını derleyerek yapmıştır. Mowday, Porter ve Steers'e (1982: 26) göre, çalışanın ve örgütün hedeflerinin birliği ve uyumudur. O'Reilly'e (1989: 17) göre, çalışanların kurumlarına olan inancını ve bağlılığını gösteren psikolojik bağlılığıdır. Robbins'e (1990: 4) göre, çalışanların kurumlarındaki işlerini sürdürme arzusudur. Newstrom'a (2007: 461) ve Pitaloka ve Sofia'ya (2014: 12) göre, çalışanların kuruluşlarıyla olan özdeşleşme derecesi ve çalışanların kuruluşlarında çalışmaya devam etme isteğinin derecesidir. Luthans'a (2011: 147) göre, çalışanların kurumlarına olan bağlılığına ilişkin tutumlarıdır.

Örgütsel bağlılık konusunun gelişimine katkı sunan yaklaşımlar bulunmaktadır. Bunlar: Becker'in Yan Bahis Yaklaşımı (1960), Kanter'in Yaklaşımı (1968), Etzioni'nin Yaklaşımı, O'Reilly ve Chatman'ın Yaklaşımı (1986), Penley ve Gould'un Yaklaşımı (1988), Allen ve Meyer'in Yaklaşımı (1990), Salancik'in Yaklaşımı ve Çoklu Bağlılık Yaklaşımı şeklindedir (Gül, 2002: 41-51). Bu çalışmada Allen ve Meyer'in Yaklaşımı temelinde şekillendirilen örgütsel bağlılık kavramı tercih edilmiştir. Allen ve Meyer'e göre şekillendirilen örgütsel bağlılık kavramı üç boyuttan oluşmaktadır. Bu boyutlar: duygusal bağlılık, devam bağlılı̆̆1 ve normatif bağlllık şeklindedir (Allen ve Meyer, 1990: 2-4; Meyer, Stanley, Herscovitch ve Topolnytsky, 2002: 21-22). Duygusal bağlılık, çalışanların kurumlarına olan duygusal bağlılığını, özdeşleşmesini ve katılımını temsil etmektedir (Allen ve Meyer, 1990: 1; 1996: 253; Konovsky ve Cropanzano, 1991: 700-702). Devam bağlılığ1, çalışanların kurumdan ayrılmaları durumunda algılanan maliyete (kayba karşı fayda) dayanmaktadır (Allen ve Meyer, 1990: 1; 1996: 253; Lamsa ve Savolainen, 1999: 298). Normatif bağlılık, çalışanların bağlı oldukları kurumlarda işlerine devam etme zorunluluğunu yansıtmaktadır (Wiener ve Vardi, 1980: 81-96; Wiener, 1982: 418-428).

İşgören performansı, endüstri ve örgüt psikolojisinin merkezinde yer alan bir kavramdır. Bu kavram için neyin gerekli olduğunun bilinmesi hem çalışanlar hem de kurumlar için çok önemlidir (Viswesvaran ve Ones, 2000: 216). Bir kurumdaki işgören performansı ne kadar yüksek ise o kurumun kazanımları da o kadar yüksek olacaktır. Bu durum kurumların etkinliği ve devamlılığı için büyük önem arz etmektedir (İraz ve Akgün, 2011: 228). Çünkü işgören performansı sayesinde bir açıdan kurumlardaki çalışan bireyler ödüllendirilirken bir açıdan da kurumlardaki eksiklikler gözlemlenmektedir (Nergiz ve Yılmaz, 2016: 60; Uludă̆, 2018: 180). Bu kavramın sağladığ 1 yararlardan birisi de çalışanlarda kurumlarına karşı eşitlik ve adalet duygusunun oluşmasının sağlanmasıdır (Chen, Yuan, Cheng ve Seifert, 2016: 237; Ağırkaya ve Erdem, 2018: 23-60; Çakıl ve Güney, 2019: 47). 
İşgören performansıyla ilgili bazı tanımlara bu paragrafta yer verilmiştir. Busch ve Bush'a (1978: 440), Kohli'ye (1985: 427) ve Babin ve Boles'e (1998: 82) göre işgören performans1, bir çalışanın, diğer çalışma arkadaşlarına göre, işle ilgili davranışlardaki ve sonuçlardaki etkinlik düzeyidir. McCloy, Campbell ve Cudeck'e (1994: 493) göre, kurumun amacina ulaşmasını sağlayan eylem veya eylemler bütünüdür. Smith ve Goddard'a (2002: 250) göre, görevlerin sayısında, kalitesinde, güncelliğinde ve masrafların azalmasında yardımcı olmasıdır. Çekmecelioğlu'na (2014: 25) göre, çalışanların işlerini yerini getirmek için göstermiş oldukları çabaların bir sonucudur.

Sanayi devriminden sonra işgörenlerle ilgili konular makine ile ilgili konulardan daha az zikredilmeye başlanmıştı. Bu durumun, Roethlisberger ve Dickson (2003) tarafından 20.000 çalışanı olan Hawthorne adlı şirkette 1920'li yılların başında yapılan bir araştırmayla değişmeye başladığı görülmüştür. Bu araştırmadan sonra çalışanların iş tatminine yönelik çalışmalara olan ilgisinde artış gözlemlenmiştir. Böylelikle iş tatmini kavramı 1930'lu yıllardan itibaren yönetim alanındaki araştırmacılar tarafından tercih edilen popüler konulardan birisi haline dönüşmüştür (Davidson, 2001: 555; Demir, 2006: 157). Bu konunun araştırmacılar tarafından tercih edilmesinin iki temel nedeni bulunmaktadır. Birincisi, bireyler çalışma hayatlarının büyük bir bölümünü iş yerinde geçirdiklerinden dolayı bu kavramla ilgili durumların anlaşılması, bireylerin yaşamdan almış oldukları mutluluk düzeyinin önemli bir ölçüde iyileşmesine olanak sağlayacak olmasıdır. İkincisi, bireylerin iş tatmini düzeyi ne kadar yüksek olursa kurumların üretkenlik durumu ve karlılık miktarı da o kadar yüksek olacağ1 düşüncesidir (Gruneberg, 1979: 1-2; Clark, 1996: 189).

Bu kavramın gelişimine katkı sunan araştırmacıların başında Robert Hoppock ve Louis E. Davis gelmektedir (Gruneberg, 1979: 4-33). İş tatmini kavramı, birçok teoriye (Maslow Teorisi, Eşitlik Teorisi, Herzberg'in Çift Faktör Teorisi vb.) dayanmakta ve bu teorilerde önemli bir unsur olduğu ifade edilmektedir (Spector, 1999: 177-180; Aziri, 2011: 77-86). Çalışanların iş tatmini düzeylerinin belirlenmesi için anketler geliştirilmiştir. Bu anketlerden en çok tercih edilenleri Weiss vd.'nin (1966) geliştirmiş olduğu Minnesota İş Tatmini Ölçeği (Minnesota Satisfaction Questionnaire-MSQ), Smith, Kendall ve Hulin'in (1969) geliştirmiş olduğu İş Betimlemesi Ölçeği (Job Descriptive Index-JID) ve Ironson vd.'nin (1989) geliştirmiş olduğu Genel İş Skalası Ölçeği (Job in General Scale-JID) şeklindedir (Spector, 1999: 221). Bu çalışmada Minnesota İş Tatmini Ölçeği kullanılmıştır. Bu ölçek iş tatminini, içsel tatmin ve dişsal tatmin olmak üzere iki yönden incelemektedir. İçsel tatmin, işin kendisini, ödüllendirmeyi, başarıyı, gelişimi ve sorumluluğu kapsamaktadır. Dışsal tatmin, ücreti (maaşı), kurum (şirket) politikalarını, teknik yeterliliği, iş arkadaşlarıyla olan ilişkileri ve çalışma (kadro) durumunu içermektedir (Wernimont, 1966: 43).

İş tatmini ile ilgili literatürde birçok tanım yer almaktadır. Schaffer'a (1953: 3) göre, çalışanların işleriyle ilgili ihtiyaçların karşılanması durumudur. Çalışanların ihtiyaçları ne kadar azaltılırsa iş tatmini o kadar artacaktır. Locke'ye (1969: 316) göre, çalışanların iş değerlerine ulaşmasını sağlamak veya kolaylaştırmak amacıyla işinin değerlendirilmesinden dolayı ortaya çıkan zevkli bir duygusal durum halidir. Schneider ve Snyder'a (1975: 319) göre, çalışanların içsel tepkilerinin yani duygularının algılanması durumudur. Spector'a (1999: 197) göre, çalışanların işlerini sevme düzeyidir. Muchinsky'e (2006: 313) göre, bir çalışanın işinden elde ettiği zevk derecesidir. Aşan ve Özyer'e (2008: 135) göre, çalışanların 
genel olarak işe veya işin birtakım kısımlarına karşı hissetmiş olduğu duygular ve tutumlar bütünüdür.

Literatürde örgütsel bağlılık, işgören performansı ve iş tatmini konuları (tek veya ikili değişkenler şeklinde) temelinde üniversite personeline yönelik yapılmış araştırmalar bulunmaktadır. Üniversitelerdeki idari personel (Kaur, 1984; Brown ve Sargeant, 2007; Schroder, 2008; Smeenk, Teelken, Eisinga ve Dooreward, 2008; Güneş, Bayraktaroğlu ve Özen Kutanis, 2009; Bos, Donders, Bouwman-Brouwer ve Van der Gulden, 2009; Smeenk, Teelken, Eisinga ve Dooreward, 2009; Bakanauskiene, Bendaraviciene ve Krikstolaitis, 2010; Love, Tatman ve Chapman, 2010; Faramarzi ve Khodaverdizadeh, 2013; Moazzezi, Sattari ve Bablan, 2014; Candan, Canbolat ve Öksüz, 2015; Barzoki ve Sarand, 2015; Ekşi, Dilmaç, Yaman ve Hamarta, 2015; Fard ve Karimi, 2015; Naik, 2015; Bağc1 ve Demir, 2017; Kalantari vd., 2018; Cindiloğlu Demirer, 2019; Swaidan ve Adwan, 2019; Güler ve Bircan, 2020; Jabbar, Hussin, Hashmi ve Jafri, 2020; Marliati, Hamid ve Yusuf, 2020; Zeer, Alkhatib ve Alshrouf, 2020), öğretim elemanı (Malik, Nawab, Naeem ve Danish, 2010; Kahya, 2013; Zeynel ve Çarıkçı, 2015; Bayrak Kök, 2016; Atılgan, 2017; Karadirek ve Genç, 2019; Mete ve Sökmen, 2019) ile öğretim elemanı ve idari personel (Çöl ve Gül, 2005; Kayalar ve Özmutaf, 2009; Aydemir ve Erşan, 2011; Adekola, 2012; Bendaraviciene ve Bakanauskiene, 2012; Nwani ve Udechukwu, 2014; Hijazi, Kasim ve Daud, 2016; Robson, Udo ve Efiok, 2016; Çevik ve Şimşek, 2017; Bozer ve Yanık, 2020) üzerine çalışmalar yapılmıştır. Üniversite personelleri üzerine yapılmış çalışmalar incelendiğinde bu üç değişkenin (örgütsel bağlılık, işgören performansı ve iş tatmini) birlikte incelendiği bir araştırmaya rastlanılmamıştır. Bu çalışmanın amacı, üniversite bünyesindeki personellerin örgütsel bağlılık ile işgören performansı arasındaki ilişkide iş tatmininin aracılık rolünün belirlenmesidir.

\section{KAVRAMSAL ÇERÇEVE}

\section{1. Örgütsel Bağlılık ve İşgören Performansı İle İlgili Yapılan Çalışmalar}

Örgütsel bağlılık ve işgören performansı değişkenleri birlikte kullanılarak idari personel, banka çalışanları, belediye çalışanları, kamu sektörü çalışanları, özel güvenlik çalışanları ve sivil toplum kuruluşu üyeleri üzerine araştırmalar yapılmıştır. Bu araştırmalarda etik iklim algısı (Ahmetoğulları ve Çatı, 2017), insan kaynakları uygulamaları (Smeenk vd., 2008; 2009), iş motivasyonu (Çağırağası, 2013), liderlik tarzları (Doğanay ve Şen, 2016), liderlik tarzları ve ayrılma niyeti (Çekmecelioğlu, 2014) ve örgütsel engeller (Çekmecelioğlu ve Pelenk, 2015) değişkenleri de kullanılmıştır. Sadece örgütsel bağlılık ve işgören performansının birlikte kullanıldığı çalışmalar Özkutlu (2008), İraz ve Akgün (2011) ve Uludağ (2018) şeklindedir. Tablo 1'de örgütsel bağlılık ve işgören performansı ile ilgili üniversitede ve kamu sektöründe yapılmış çalışmalara yer verilmiştir. 
Tablo 1: Örgütsel Bağlılık ve İşgören Performansı İle İlgili Çalışmalar

\begin{tabular}{|c|c|c|c|c|}
\hline Yazar(lar) & $\nexists$ & Örneklem & $\begin{array}{c}\text { Diğer } \\
\text { Değişkenler }\end{array}$ & Sonuç(lar) \\
\hline $\begin{array}{c}\text { Smeenk } \\
\text { vd. }\end{array}$ & $\stackrel{\infty}{8}$ & $\begin{array}{c}\text { İdari } \\
\text { Personel }\end{array}$ & $\begin{array}{c}\text { İnsan } \\
\text { Kaynakları } \\
\text { Uygulamaları }\end{array}$ & $\begin{array}{l}\text { Düşük, orta ve yüksek derecedeki insan kaynakları } \\
\text { uygulamaları idari personelin iş performansını } \\
\text { etkilemektedir. } \\
\text { Maaş ve araştırma geliştirme faaliyetleri düşük düzeyde } \\
\text { insan kaynakları uygulamaları olan ülkelerdeki idari } \\
\text { personelin iş performansını olumsuz yönde etkilemektedir. } \\
\text { Maaş ve araştırma geliştirme faaliyetleri orta düzeyde } \\
\text { insan kaynakları uygulamaları olan ülkelerdeki idari } \\
\text { personelin iş performansını olumlu yönde etkilemektedir. } \\
\text { İstihdam güvenliği durumu sadece orta düzeyde insan } \\
\text { kaynakları uygulamaları olan ülkelerdeki idari personelin } \\
\text { iş performansını olumlu yönde etkilemektedir. } \\
\text { Düşük düzeyde insan kaynakları uygulamaları ile iş } \\
\text { performansı arasındaki ilişkide örgütsel bağlılığın aracılık } \\
\text { etkisi yoktur. } \\
\text { Orta düzeyde insan kaynakları uygulamaları ile iş } \\
\text { performansı arasındaki ilişkide örgütsel bağlılığın aracıllk } \\
\text { etkisi vardır. } \\
\text { Yüksek düzeyde insan kaynakları uygulamaları ile iş } \\
\text { performansı arasındaki ilişkide örgütsel bağlılığın hem } \\
\text { doğrudan hem de dolaylı olarak aracılık etkisi vardır. }\end{array}$ \\
\hline $\begin{array}{c}\text { Smeenk } \\
\text { vd. }\end{array}$ & 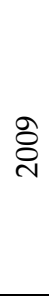 & $\begin{array}{c}\text { İdari } \\
\text { Personel }\end{array}$ & $\begin{array}{c}\text { İnsan } \\
\text { Kaynakları } \\
\text { Uygulamaları }\end{array}$ & $\begin{array}{l}\text { İnsan kaynakları uygulamaları ile iş performansı arasında } \\
\text { anlamlı ve pozitif yönlü bir ilişki vardır. } \\
\text { İnsan kaynakları uygulamaları, iş performansını olumlu } \\
\text { yönde etkilemektedir. } \\
\text { Avrupa'daki üniversitelerde çalışan idari personelin } \\
\text { yönetimsel açıdan bir çelişki içinde olmadığı sonucu elde } \\
\text { edilmiştir. }\end{array}$ \\
\hline Özkutlu & 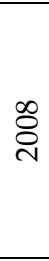 & $\begin{array}{c}\text { Kamu } \\
\text { Sektörü } \\
\text { Çalışanları }\end{array}$ & & $\begin{array}{l}\text { Çalışanların örgütsel bağlılık düzeyleri orta seviyededir. } \\
\text { Çalışanların iş performans düzeyi yüksek seviyededir. } \\
\text { Duygusal ve devam bağlılığı ile iş performansı arasında } \\
\text { anlamlı ve pozitif yönde bir iliş̧ki vardır. } \\
\text { Normatif bağlılık ile iş performansı arasında anlamlı bir } \\
\text { ilişki tespit edilememiştir. }\end{array}$ \\
\hline $\begin{array}{c}\text { Doğanay } \\
\text { ve Şen }\end{array}$ & $\begin{array}{l}0 \\
\stackrel{0}{0}\end{array}$ & $\begin{array}{l}\text { Belediye } \\
\text { Çalışanları }\end{array}$ & $\begin{array}{l}\text { Liderlik } \\
\text { Tarzları }\end{array}$ & 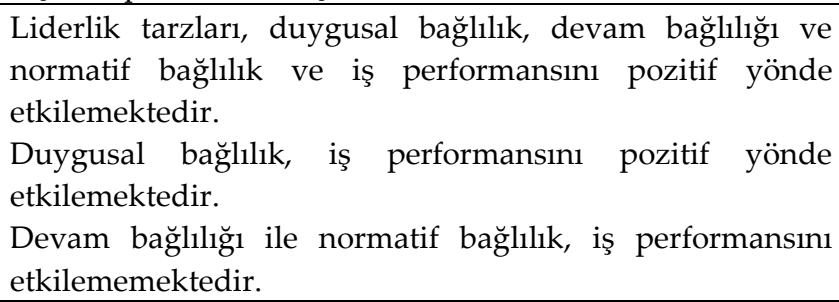 \\
\hline Uludağ & $\stackrel{\infty}{\stackrel{\infty}{2}}$ & $\begin{array}{c}\text { Kamu } \\
\text { Sektörü } \\
\text { Çalışanları }\end{array}$ & & $\begin{array}{l}\text { İşgören performansı ile duygusal bağlılık, devam bağlılığ } 1 \\
\text { ve normatif bağlılık arasında anlamlı ve pozitif yönlü bir } \\
\text { ilişki vardır. } \\
\text { İşgören performansı, duygusal bağlılığı ve normatif } \\
\text { bağlılığı pozitif yönde etkilemektedir. }\end{array}$ \\
\hline
\end{tabular}

Kurumlar, rekabet ortamında avantaj elde edebilmek için işgören performans düzeylerini yükseltmeyi arzu etmekte olup bu işgören performans düzeylerinin kısa vadeli yerine uzun vadeli bir şekilde yüksek seviyede kalmalarını hedeflerler. Rekabet ortamında kurumların öne çıkmasını sağlayan unsurlardan birisi de örgütsel bağlılık ile performans arasındaki 
ilişkidir. Örgütsel bağlılık işgörenlerin kurumlarına karşı duydukları olumlu duygu ve düşünceleri artıracağından dolayı işgörenlerin performansı üzerinde olumlu etkiler bırakmaktadır (Altun, 2019: 11). Tablo 1'deki çalışmalar ilişki ve etki sonucuna göre gruplandırılmıştır. Smeenk vd. (2008), Özkutlu (2008), İraz ve Akgün (2011), Çağırağası (2013) ve Çekmecelioğlu (2014) çalışmalarında pozitif yönlü bir ilişkinin olduğunu göstermiştir. Doğanay ve Şen (2016), Ahmetoğulları ve Çatı (2017) ve Uludağ (2018) çalışmalarında örgütsel bağlılığın işgören performansını etkilediğini tespit etmişlerdir. İlgili literatürdeki sonuçlara göre aşağıdaki hipotezler belirlenmiştir.

H1: Örgütsel bağlılık (H1a: duygusal bağl1lı; H1b: devam bağl1lı̆̆1; H1c: normatif bağlılık), işgören performansını pozitif yönlü etkilemektedir.

\section{2. Örgütsel Bağlılık ve İş Tatmini İle İlgili Yapılan Çalışmalar}

Örgütsel bağlılık ve iş tatmini konuları ile yapılmış çalışmalar örneklem ve ilişkilendirilmiş diğer konular bağlamında gruplandırılmıştır. Bu konularla idari personel, öğretim elemanları, öğretim elemanları ve idari personel, ilk ve orta okul öğretmenleri, inşaat sektörü çalışanları, lise öğretmenleri, muhasebe meslek mensupları, otel işletmeleri çalışanları, özel sektör çalışanları, kamu sektörü çalışanları, özel sektör ve kamu sektörü çalışanları, sağlık sektörü çalışanları, tekstil sektörü çalışanları, tıbbi satış elemanı ve yüzme hakemleri üzerine çalışmalar yapılmıştır. Örgütsel bağlılık ve iş tatmini konuları üzerine Bayrak Kök (2006), Brown ve Sargeant (2007), Malik vd. (2010), Adekola (2012), Güler ve Bircan (2020), Yıldırım vd. (2011), Yumuşak, Özafşarlıoğlu ve Yıldız (2013), Hoş ve Oksay (2015), Acar ve Türkoğlu (2017), Aydın vd. (2017), Özdemir vd. (2017), Özmen ve Kahraman (2017), Aksoy, Şengün ve Y1lmaz (2018), Bekmezci ve Mert (2018), Hatipoğlu ve Dündar (2018), Bora K1lınçarslan ve Küçüksüleymanoğlu (2019) ve Özkan vd. (2019) çalışmalarda bulunmuştur. Bu konularla birlikte ayrılma niyeti (Jafarova ve Sağlam, 2018), ayrılma niyeti ve iş güvencesi (Poyraz ve Kama, 2008), ayrılma niyeti ve örgütsel adalet (Mete ve Sökmen, 2019), ayrılma niyeti, psikolojik sözleşme ve psikolojik sözleşme ihlali (Mimaroğlu Özgen ve Özgen, 2010), bireycitoplumcu kültür eğilimi (Karadirek ve Genç, 2019), etik iklim algısı (Yüksel ve Düşükcan, 2019), içsel pazarlama (İşler ve Özdemir, 2010), iş motivasyonu (Zeynel ve Çarıkçı, 2015), iş motivasyonu ve örgütsel destek (Karadirek, 2020), iş sağlı̆̆ı ve güvenliği (Çınar ve Gündoğdu, 2019), işkoliklik (Yalçınsoy ve Aksoy, 2019), kişilik özellikleri (Tantekin Çelik ve Laptalı Oral, 2013), kurumsal imaj (Kahyaoğlu ve Akca, 2020), kurumsal sosyal sorumluluk (Tuzcu, 2014), liderlik tarzları (Çelik, Dedeoğlu ve İnanır, 2015; Dedeoğlu vd., 2016; Kırkpınar ve İşcan, 2018), müşteri yönelimliyi (Yolaç, 2008), örgütsel kariyer yönetimi (Büyükyılmaz, Karakule ve Karataş, 2018), örgütsel özdeşleşme ve kişi-örgüt uyumu (Sökmen ve Bıyık, 2016), örgütsel sinizm ve örgütsel güven (Fard ve Karimi, 2015), örgütsel sinizm ve psikolojik sermaye (Şen ve Mert, 2019), psikolojik sermaye (Ocak, Güler ve Basım, 2016), sosyal kaytarma (Şeşen ve Kahraman, 2014) ve tükenmişlik (Demir, 2009; Babadağ ve Arlı, 2018) konuları araştırılmıştır. Örgütsel bağlılık ve iş tatmini ile ilgili üniversitede ve kamu sektöründe yapılmış çalışmalara Tablo 2'de yer verilmiştir. 
Tablo 2: Örgütsel Bağlılık ve İş Tatmini İle İlgili Çalışmalar

\begin{tabular}{|c|c|c|c|c|}
\hline Yazar(lar) & $\nexists$ & Örneklem & $\begin{array}{c}\text { Diğer } \\
\text { Değişkenler }\end{array}$ & Sonuç(lar) \\
\hline Bayrak Kök & 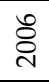 & $\begin{array}{l}\text { Öğretim } \\
\text { Elemanları }\end{array}$ & & $\begin{array}{l}\text { Öğretim elemanlarının iş tatmini ve örgütsel bağlllık düzeyleri } \\
\text { belirlenmiştir. }\end{array}$ \\
\hline $\begin{array}{l}\text { Brown ve } \\
\text { Sargeant }\end{array}$ & $\widehat{\overbrace{}}$ & $\begin{array}{l}\text { İdari } \\
\text { Personel }\end{array}$ & & $\begin{array}{l}46 \text { yaşından büyükler daha genç çalışanlara oranlara iş tatmini, örgütsel } \\
\text { bağlllığı ve inanç bağllı̆ğı daha yüksektir. } \\
\text { Doktora derecesine sahip çalışanlar lise mezunu çalışanlara oranla iş } \\
\text { tatmini ve inanç bağlılığı daha yüksektir. } \\
\text { Kurumda çalışma süresi arttıkça çalışanların örgütsel bağlılığı ve dışsal } \\
\text { iş tatmini de artmaktadır. } \\
\text { Yönetici pozisyonunda çalışanlar diğer pozisyonlarda çalışanlara oranla } \\
\text { içsel iş tatmini ve inanç bağlllığı daha yüksektir. }\end{array}$ \\
\hline Malik vd. & $\stackrel{\circ}{\circ}$ & $\begin{array}{l}\text { Öğretim } \\
\text { Elemanları }\end{array}$ & & $\begin{array}{l}\text { Örgütsel sinizm ile örgütsel güven, örgütsel bağlılık ve iş tatmini } \\
\text { arasından anlamlı ve negatif yönlü bir ilişki vardır. } \\
\text { Örgütsel bağlllık ile iş tatmini arasında anlamlı ve pozitif yönlü bir ilişki } \\
\text { vardır. } \\
\text { Örgütsel güvenin örgütsel sinizm, örgütsel bağlllık ve iş tatmini } \\
\text { üzerinde doğrudan etkisi vardır. } \\
\text { Örgütsel güvenin, örgütsel bağlllık ile iş tatmini arasındaki ilişkide } \\
\text { örgütsel sinizmin aracilı rolü bulunmaktadır. } \\
\text { Örgütsel sinizmin, örgütsel bağlllık ve iş tatmini üzerinde doğrudan } \\
\text { etkisi vardır. }\end{array}$ \\
\hline Adekola & 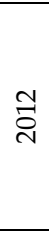 & $\begin{array}{l}\text { Öğretim } \\
\text { Elemanları } \\
\text { ve İdari } \\
\text { Personel }\end{array}$ & & $\begin{array}{l}\text { İş tatmini ile örgütsel bağlllık, duygusal bağlllık ve normatif bağlılık } \\
\text { arasında anlamlı ve pozitif yönlü bir ilişki vardır. } \\
\text { Devam bağlılığı ile iş tatmini, içsel tatmin ve dışsal tatmin arasında bir } \\
\text { ilişki yoktur. } \\
\text { Duygusal bağlılık, içsel tatmini, dişsal tatmini ve iş tatminini pozitif } \\
\text { yönlü etkilemektedir. }\end{array}$ \\
\hline $\begin{array}{l}\text { Fard ve } \\
\text { Karimi }\end{array}$ & 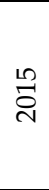 & $\begin{array}{l}\text { İdari } \\
\text { Personel }\end{array}$ & $\begin{array}{l}\text { - Örgütsel } \\
\text { Sinizm } \\
\text { - Örgütsel } \\
\text { Güven }\end{array}$ & $\begin{array}{l}\text { Örgütsel bağlılığın, iş tatminine (çalışma alanından memnuniyet, } \\
\text { denetim ve maaş) pozitif yönlü bir etkisi vardır. } \\
\text { Örgütsel bağllık düzeyleri yüksek olan akademisyenler, iş, denetim, } \\
\text { ücret, çalışma arkadaşları ve işte yükselme fırsatı açısından tatmin } \\
\text { olmaktadırlar. }\end{array}$ \\
\hline $\begin{array}{c}\text { Zeynel ve } \\
\text { Çarıkçı }\end{array}$ & 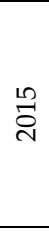 & $\begin{array}{l}\text { Öğretim } \\
\text { Elemanları }\end{array}$ & $\begin{array}{c}\text { İş } \\
\text { Motivasyonu }\end{array}$ & $\begin{array}{l}\text { Mesleki motivasyon ile iş tatmini ve örgütsel bağlılık düzeyleri arasında } \\
\text { anlamlı ve pozitif yönde bir ilişki vardır. } \\
\text { İş tatmini ile örgütsel bağlılık düzeyleri arasında anlamlı ve pozitif } \\
\text { yönde bir ilişki vardır. } \\
\text { Mesleki motivasyon, iş tatminini ve örgütsel bağlılığı etkilemektedir. } \\
\text { İş tatmini, örgütsel bağlllığı etkilemektedir. }\end{array}$ \\
\hline $\begin{array}{c}\text { Karadirek } \\
\text { ve Genç }\end{array}$ & 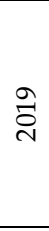 & $\begin{array}{l}\text { Öğretim } \\
\text { Elemanlar }\end{array}$ & $\begin{array}{c}\text { Bireyci- } \\
\text { Toplumcu } \\
\text { Kültür Eğilimi }\end{array}$ & $\begin{array}{l}\text { Bireycilik kültür ile iş tatmini ve örgütsel bağlılık arasında anlamlı bir } \\
\text { ilişki yoktur. } \\
\text { Toplumculuk kültür ile iş tatmini ve örgütsel bağlılık arasında anlamlı } \\
\text { ve pozitif yönlü bir ilişki vardır. } \\
\text { İş tatmininin örgütsel bağlılık üzerindeki etkisinde bireycilik ve } \\
\text { toplumculuk kültürün rolü yoktur. }\end{array}$ \\
\hline $\begin{array}{l}\text { Mete ve } \\
\text { Sökmen }\end{array}$ & $\overrightarrow{\vec{े}}$ & $\begin{array}{l}\text { Öğretim } \\
\text { Elemanları }\end{array}$ & $\begin{array}{l}\text { - Ayrılma } \\
\text { Niyeti } \\
\text { - Örgütsel } \\
\text { Adalet }\end{array}$ & $\begin{array}{l}\text { Örgütsel adalet ile iş tatmini ve örgütsel bağlılık arasında anlamlı ve } \\
\text { pozitif yönlü bir ilişki vardır. } \\
\text { Örgütsel adalet ile ayrılma niyeti arasında anlamlı ve negatif yönlü bir } \\
\text { ilişki vardır. } \\
\text { Örgütsel adalet ile iş performansı arasındaki ilişkide örgütsel bağlılığın } \\
\text { aracılık rolü bulunmaktadır. } \\
\text { Örgütsel adalet ile ayrılma niyeti arasındaki ilişkide örgütsel bağlılığın } \\
\text { aracılık rolü bulunmaktadır. }\end{array}$ \\
\hline $\begin{array}{l}\text { Güler ve } \\
\text { Bircan }\end{array}$ & ત્તิ & $\begin{array}{l}\text { İdari } \\
\text { Personel }\end{array}$ & & $\begin{array}{l}\text { Örgütsel bağlılık ile iş tatmini arasında pozitif yönlü ve anlamlı bir ilişki } \\
\text { vardır. } \\
\text { Örgütsel bağlllık, iş tatminini etkilemektedir. } \\
\text { Devlet üniversitesi çalışanlarını örgütsel bağlllık düzeyleri özel } \\
\text { üniversite çalışanlarına oranla daha yüksektir. }\end{array}$ \\
\hline
\end{tabular}


Tablo 2 Devami..

\begin{tabular}{|c|c|c|c|c|}
\hline $\begin{array}{l}\text { İşler ve } \\
\text { Özdemir }\end{array}$ & 옳 & $\begin{array}{l}\text { Sağlık } \\
\text { Sektörü } \\
\text { Çalışanları }\end{array}$ & $\begin{array}{c}\text { İçsel } \\
\text { Pazarlama }\end{array}$ & $\begin{array}{l}\text { İçsel pazarlama, iş tatminini anlamlı ve pozitif yönde etkilemektedir. } \\
\text { İçsel pazarlama, duygusal bağlllı anlaml ve pozitif yönde } \\
\text { etkilemektedir. } \\
\text { İçsel pazarlama, devam ve normatif bağlllık üzerinde bir etkisi } \\
\text { bulunmamaktadır. }\end{array}$ \\
\hline $\begin{array}{l}\text { Hoş ve } \\
\text { Oksay }\end{array}$ & 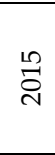 & $\begin{array}{l}\text { Sağlık } \\
\text { Sektörü } \\
\text { Çalışanları }\end{array}$ & & $\begin{array}{l}\text { Dişsal ve içsel tatmin ile duygusal bağlılık, devam bağllı̆̆̆ ve normatif } \\
\text { bağlllık arasında anlamlı ve pozitif yönde bir ilişki vardır. } \\
\text { Devam bağlılığı en fazla dışsal tatminden etkilemektedir. } \\
\text { Duygusal ve normatif bağlllık en fazla içsel tatmin etkilemektedir. }\end{array}$ \\
\hline $\begin{array}{c}\text { Sökmen ve } \\
\text { Biyık }\end{array}$ & 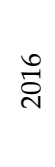 & $\begin{array}{c}\text { Kamu } \\
\text { Sektörü } \\
\text { Çalışanları }\end{array}$ & $\begin{array}{l}\text { - Örgütsel } \\
\text { Özdeşleşme } \\
\text { - Kişi-Örgüt } \\
\text { Uyumu }\end{array}$ & $\begin{array}{l}\text { Örgütsel bağlllık ile örgütsel özdeşleşme, kişi-örgüt uyumu ve iş tatmini } \\
\text { arasında anlamlı ve pozitif yönde bir ilişki vardır. } \\
\text { Örgütsel bağlllık, örgütsel özdeşleşmeyi, kişi-örgüt uyumunu ve iş } \\
\text { tatminini pozitif yönde etkilemektedir. }\end{array}$ \\
\hline $\begin{array}{l}\text { Acar ve } \\
\text { Türkoğlu }\end{array}$ & 令 & $\begin{array}{c}\text { Kamu } \\
\text { Sektörü } \\
\text { Çalışanları }\end{array}$ & & $\begin{array}{l}\text { İş tatmini ile örgütsel bağlılık arasında anlamlı ve pozitif yönde bir ilişki } \\
\text { vardır. }\end{array}$ \\
\hline $\begin{array}{l}\text { Bekmezci ve } \\
\text { Mert }\end{array}$ & $\stackrel{\infty}{\stackrel{\sim}{\sim}}$ & $\begin{array}{c}\text { Kamu } \\
\text { Sektörü } \\
\text { Çalışanları }\end{array}$ & & $\begin{array}{l}\text { İş tatmini ile örgütsel bağlılık arasında anlamlı ve pozitif yönde bir iliş̧ki } \\
\text { vardır. } \\
\text { Üst kademede görev yapanların alt kademede görev yapanlara göre } \\
\text { daha yüksek oranda iş tatmini düzeyine sahiptirler. } \\
\text { Örgütsel bağlllık açısından örgüt kademelerinde bir farklılık tespit } \\
\text { edilememiştir. }\end{array}$ \\
\hline $\begin{array}{l}\text { Kırkpınar ve } \\
\text { İşcan }\end{array}$ & $\stackrel{\infty}{\stackrel{\circ}{*}}$ & $\begin{array}{l}\text { Sağlık } \\
\text { Sektörü } \\
\text { Çalışanları }\end{array}$ & $\begin{array}{l}\text { Liderlik } \\
\text { Tarzları }\end{array}$ & $\begin{array}{l}\text { Liderlik tarzları ile iş tatmini ve örgütsel bağlılık arasında anlamlı bir } \\
\text { ilişki vardır. } \\
\text { Liderlik tarzları, iş tatminini ve örgütsel bağlılığı pozitif yönde } \\
\text { etkilemektedir. } \\
\text { İş tatmini, örgütsel bağlılığı pozitif yönde etkilemektedir. }\end{array}$ \\
\hline Şen ve Mert & ڤે & $\begin{array}{c}\text { Kamu } \\
\text { Sektörü } \\
\text { Çalışanları }\end{array}$ & $\begin{array}{l}\text { - Örgütsel } \\
\text { Sinizm } \\
\text { - Psikolojik } \\
\text { Sermaye }\end{array}$ & $\begin{array}{l}\text { Psikolojik sermaye ile iş tatmini ve örgütsel bağlılık arasında anlamlı ve } \\
\text { pozitif yönlü bir ilişki vardır. } \\
\text { Psikolojik sermaye ile sinizm arasında anlamlı ve negatif yönlü bir ilişki } \\
\text { vardır. } \\
\begin{array}{l}\text { Psikolojik sermaye, iş tatminini, örgütsel bağlılı̆̆ı ve sinizmi } \\
\text { etkilemektedir. }\end{array}\end{array}$ \\
\hline $\begin{array}{c}\text { Yalçınsoy ve } \\
\text { Aksoy }\end{array}$ & ڤે & $\begin{array}{c}\text { Kamu } \\
\text { Sektörü } \\
\text { Çalışanları }\end{array}$ & İşkoliklik & $\begin{array}{l}\text { İşkoliklik ile iş tatmini ve örgütsel bağlılık arasında anlamlı ve pozitif } \\
\text { yönlü bir ilişki vardır. } \\
\text { Örgütsel bağlllık, iş tatminini ve işkolikliği etkilememektedir. }\end{array}$ \\
\hline
\end{tabular}

Bayrak Kök (2006: 300) çalışmasında, örgütsel bağlılık ve iş tatmini arasındaki ilişki ve etkiye yönelik dört model olduğunu belirtmiştir. Bu modeller; (a) iş tatmini örgütsel bağl1lı̆g etkiler, (b) örgütsel bağlılık iş tatminini etkiler, (c) iş tatmini ile örgütsel bağlllık birbirini etkiler ve (d) iş tatmini ile örgütsel bağlllık birbirini etkilemez şeklindedir. Bu çalışmada model $b$ test için belirlenmiştir. Araştırma için önerilen hipotezler aşağıda yer almaktadır.

H2: Örgütsel bağl1lık (H2a: duygusal bağl1lık; H2b: devam bağl1lı̆̆; H2c: normatif bağl1lık), iş tatminini (içsel tatmin) pozitif yönlü etkilemektedir.

H2: Örgütsel bağlılık (H2d: duygusal bağl1lı; H2e: devam bağl1lı̆̆1; H2f: normatif bağlılık), iş tatminini (dışsal tatmin) pozitif yönlü etkilemektedir.

\section{3. İş Tatmini ve İşgören Performansı İle İlgili Yapılan Çalışmalar}

İş tatmini ve işgören performansı üzerine yapılmış çalışmalar bu başlık altında özetlenmiştir. $\mathrm{Bu}$ konular ile idari personel, öğretim elemanları, öğretim elemanları ve idari personel, belediye çalışanları, futbol hakemleri, hizmet sektörü çalışanları, kamu sektörü çalışanları, muhasebe meslek mensupları, otel işletmeleri çalışanları ve özel sektör çalışanları üzerine araştırmalar yapılmıştır. Literatürdeki iş tatmini ve iş gören performansının birlikte 
kullanıldığı çalışmalar Nergiz ve Yılmaz (2016), Atılgan (2017) ve Çakıl ve Güney (2019) şeklindedir. Bu kavramların yanında ayrılma niyeti ve affetme stilleri (Kale ve Aknar, 2020), içsel pazarlama (Eşitti ve Buluk, 2018), kültür ve dönüşüm (Marliati, Hamid ve Yusuf, 2020), liderlik tarzları (Bıyık, Şimşek ve Erden, 2017; Beğenirbaş ve Can Yalçın, 2020; Bozdoğan ve Aksoy, 2020; Çöp ve Doğanay, 2020), örgütsel sinizm (Kahya, 2013), örgütsel vatandaşlık (Bozer ve Yanık, 2020), stres (Koca ve Yıldız, 2018), stres ve kontrol odağ 1 (Tekin ve Deniz, 2019) ve tutkunluk (Şahin ve Çankır, 2018) kavramları da birlikte kullanılmıştır. İş tatmini ile işgören performansı arasındaki ilişkiye yönelik olarak üniversitede ve kamu sektöründe yapılmış çalışmalar Tablo 3'te gösterilmektedir.

Tablo 3: İş Tatmini ve İşgören Performansı İle İlgili Çalışmalar

\begin{tabular}{|c|c|c|c|c|}
\hline Yazar(lar) & $\nexists$ & Örneklem & $\begin{array}{l}\text { Diğger } \\
\text { Değişkenl } \\
\text { er }\end{array}$ & Sonuç(lar) \\
\hline Kahya & $\stackrel{m}{\stackrel{2}{\nu}}$ & $\begin{array}{l}\text { Öğretim } \\
\text { Elemanları }\end{array}$ & $\begin{array}{l}\text { Örgütsel } \\
\text { Sinizm }\end{array}$ & $\begin{array}{l}\text { Örgütsel sinizm, iş tatminini ve iş performansını anlamlı ve } \\
\text { negatif yönde etkilemektedir. } \\
\text { İş tatmini, iş performansını anlamlı ve pozitif yönde } \\
\text { etkilemektedir. } \\
\text { Örgütsel sinizm ile iş performansı arasındaki ilişkide iş } \\
\text { tatmininin aracılık etkisi bulunmaktadır. }\end{array}$ \\
\hline Atılgan & $\stackrel{\curvearrowright}{\stackrel{\curvearrowright}{\curvearrowright}}$ & $\begin{array}{l}\text { Öğretim } \\
\text { Elemanları }\end{array}$ & & $\begin{array}{l}\text { İse devamsızlık ve disiplinsizlik (düşük iş performansı) ile } \\
\text { ödüllendirme, çalışma şartları ve iş arkadaşlarıyla iletişim (iş } \\
\text { tatmini) arasında anlamlı ve negatif yönde bir ilişki vardır. } \\
\text { İşe devamsızlık ve disiplinsizlik (düşük iş performansı), } \\
\text { ödüllendirme, çalışma şartları ve iş arkadaşlarıyla iletişim (iş } \\
\text { tatmini) anlamlı ve negatif yönde etkilemektedir. }\end{array}$ \\
\hline $\begin{array}{l}\text { Bozer ve } \\
\text { Yanık }\end{array}$ & ๙ิ & $\begin{array}{l}\text { Öğretim } \\
\text { Elemanları } \\
\text { ve İdari } \\
\text { Personel }\end{array}$ & $\begin{array}{l}\text { Örgütsel } \\
\text { Vatandaşlı } \\
\text { k }\end{array}$ & $\begin{array}{l}\text { Örgütsel vatandaşlık davranışı ile iş tatmini ve iş performansı } \\
\text { arasında anlamlı ve pozitif yönlü bir ilişki vardır. } \\
\text { Demografik özellikler ile örgütsel vatandaşlık davranışı, iş } \\
\text { tatmini ve iş performansı arasında anlamlı farklılıklar } \\
\text { incelenmiştir. }\end{array}$ \\
\hline $\begin{array}{l}\text { Marliati } \\
\text { vd. }\end{array}$ & ๙ิ & $\begin{array}{c}\text { İdari } \\
\text { Personel }\end{array}$ & $\begin{array}{l}\text { - Kültür } \\
\text { - Dönüşüm }\end{array}$ & $\begin{array}{l}\text { Dönüşümün iş tatminine ve iş performansına direkt etkisi } \\
\text { vardır. } \\
\text { Örgütsel kültürün iş tatminine ve iş performansına direkt etkisi } \\
\text { vardır. } \\
\text { İş tatmininin iş performansına direkt etkisi vardır. } \\
\text { Dönüşümün ve örgütsel kültürün iş tatminine dolaylı etkisi } \\
\text { vardır. }\end{array}$ \\
\hline $\begin{array}{l}\text { Çakıl ve } \\
\text { Güney }\end{array}$ & $\stackrel{\overbrace{}}{\grave{2}}$ & $\begin{array}{l}\text { Belediye } \\
\text { Çalışanları }\end{array}$ & & $\begin{array}{l}\text { İş tatmini ile iş performansı arasında anlamlı ve pozitif yönlü bir } \\
\text { ilişki vardır. }\end{array}$ \\
\hline $\begin{array}{l}\text { Bozdoğan } \\
\text { ve Aksoy }\end{array}$ & ๙ิ & $\begin{array}{l}\text { Kamu } \\
\text { Sektörü } \\
\text { Çalışanları }\end{array}$ & $\begin{array}{l}\text { Liderlik } \\
\text { Tarzları }\end{array}$ & $\begin{array}{l}\text { Dönüşümsel liderlik ile iş tatmini ve iş performansı arasında } \\
\text { anlamlı ve pozitif yönlü bir ilişki vardır. } \\
\text { Dönüşümsel liderlik, iş tatminini ve iş performansını pozitif } \\
\text { yönlü etkilemektedir. }\end{array}$ \\
\hline
\end{tabular}

Judge, Thoresen, Bono ve Patton (2001: 377) çalışmasında iş tatmini ile işgören performansı arasındaki ilişki ve etkiyi gösteren yedi model olduğunu göstermiştir. Bu modeller; (a) iş tatmini işgören performansını etkiler, (b) işgören performansı iş tatminini etkiler, (c) iş tatmini ile işgören performansı birbirini etkiler, $(\mathrm{d})$ bir başka değişken iş tatminini ve işgören performansını etkiler, (e) iş tatmini ile işgören performansı arasındaki ilişkide bir başka değişkenin aracılık rolü vardır, (f) iş tatmini ile işgören performansı birbirini etkilemez ve (g) 
iş tatmini işgören performansını dolaylı olarak etkiler şeklindedir. Bu çalışmada model a test için seçilmiştir. Araştırma için belirlenen hipotezler aşağıda gösterilmektedir.

H3: İş tatmini (H3a: içsel tatmin; H3b: dışsal tatmin), işgören performansını pozitif yönlü etkilemektedir.

\section{4. Örgütsel Bağlılık, İşgören Performansı ve İş Tatmini İle İlgili Yapılan Çalışmalar}

Literatürde örgütsel bağlılık, işgören performansı ve iş tatmini konularının sadece üçünün birlikte kullanılarak yapıldığı bir araştırmaya (Karakoç, 2018) rastlanılmıştır. Ayrıca bu üç konuyla birlikte işkoliklik (Arsezen, 2017), kültür ve örgütsel iletişim (Özpehlivan, 2019), örgütsel vatandaşlık (Altaş ve Çekmecelioğlu, 2007), performans güçlendirme (Tunay, 2019) ile ücret (Düzgün ve Marşap, 2018) konuları araştırılmıştır. Bu konular ile otel işletmeleri çalışanları, otomotiv sektörü çalışanları, sigorta acentesi çalışanları, sigorta sektörü çalışanları ve tekstil sektörü çalışanları üzerine uygulamalar yapılmıştır. Örgütsel bağlılık, işgören performansı ve iş tatminiyle ilgili olarak yapılmış çalışmalar Tablo 4'te gösterilmektedir.

Tablo 4: Örgütsel Bağlılık, İşgören Performansı ve İş Tatminiyle İlgili Çalışmalar

\begin{tabular}{|c|c|c|c|c|}
\hline Yazar(lar) & $\nexists$ & Örneklem & $\begin{array}{c}\text { Diğer } \\
\text { Değişkenler }\end{array}$ & Sonuç(lar) \\
\hline $\begin{array}{c}\text { Altaş ve } \\
\text { Çekmecelioğlu }\end{array}$ & స్요 & $\begin{array}{l}\text { Otomotiv } \\
\text { Sektörü } \\
\text { Çalışanları }\end{array}$ & $\begin{array}{c}\text { Örgütsel } \\
\text { Vatandaşlık }\end{array}$ & $\begin{array}{l}\text { Duygusal ve normatif bağlılık, iş performansını pozitif } \\
\text { yönde etkilemektedir. } \\
\text { Normatif bağlılık ile iş tatmini, iş performansını pozitif } \\
\text { yönde etkilemektedir. } \\
\text { Normatif bağlılık, iş tatmini ve örgütsel vatandaşlık } \\
\text { davranışının bazı boyutlarının iş performansını pozitif } \\
\text { yönde etkilemektedir. }\end{array}$ \\
\hline Arsezen & 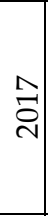 & $\begin{array}{l}\text { Otel } \\
\text { İşletmeleri } \\
\text { Çalışanları }\end{array}$ & İşkoliklik & $\begin{array}{l}\text { İşkoliklik algısı ile iş tatmini, duygusal bağlılık ve iş } \\
\text { performansı arasında anlamlı ve pozitif yönde bir ilişki } \\
\text { vardır. } \\
\text { İşkoliklik algısının iş performansına ve iş tatminine } \\
\text { etkisinde duygusal bağlılık aracılık rolü bulunmaktadır. }\end{array}$ \\
\hline $\begin{array}{l}\text { Düzgün ve } \\
\text { Marşap }\end{array}$ & $\stackrel{\infty}{\stackrel{\infty}{ٍ}}$ & $\begin{array}{l}\text { Otel } \\
\text { İşletmeleri } \\
\text { Çalışanları }\end{array}$ & Ücret & $\begin{array}{l}\text { Ücret algısı ile performans algısı, iş tatmini (içsel ve } \\
\text { dışsal) ve örgütsel bağlılık (duygusal bağlılık ve devam } \\
\text { bağlılığı) arasında anlamlı ve pozitif yönde bir ilişki } \\
\text { vardır. } \\
\text { Ücret algısı, performans algısını, iş tatminini (içsel ve } \\
\text { dışsal) ve örgütsel bağlılığı (devam bağlılığı) } \\
\text { etkilemektedir. } \\
\text { Ücret algısı, duygusal bağlılığı etkilememektedir. }\end{array}$ \\
\hline Karakoç & $\stackrel{\infty}{\stackrel{\infty}{ٍ}}$ & $\begin{array}{l}\text { Sigorta } \\
\text { Acentesi } \\
\text { Çalışanları }\end{array}$ & & $\begin{array}{l}\text { Örgütsel bağlılık, işgören performansı ve iş tatmini } \\
\text { arasında anlamlı ve pozitif yönlü ilişki vardır. } \\
\text { İş tatmininin örgütsel bağlılık ve işgören performansı } \\
\text { üzerinde pozitif yönlü bir etkisi vardır. }\end{array}$ \\
\hline Tunay & 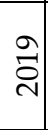 & $\begin{array}{c}\text { Sigorta } \\
\text { Sektörü } \\
\text { Çalışanları }\end{array}$ & $\begin{array}{l}\text { Performans } \\
\text { Güçlendirme }\end{array}$ & $\begin{array}{l}\text { Performans güçlendirmenin örgütsel bağllıı, işgören } \\
\text { performansı ve iş tatmini üzerinde pozitif yönlü bir etkisi } \\
\text { vardır. }\end{array}$ \\
\hline Özpehlivan & 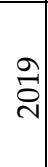 & $\begin{array}{c}\text { Tekstil } \\
\text { Sektörü } \\
\text { Çalışanları }\end{array}$ & $\begin{array}{l}\text { - Kültür } \\
\text { - Örgütsel } \\
\text { İletişim }\end{array}$ & $\begin{array}{l}\text { Kültür ile iş tatmini, örgütsel bağlılık, örgütsel iletişim ve } \\
\text { performans arasında anlamlı bir ilişki vardır. } \\
\text { Kültürr, iş tatminini, örgütsel bağlılığı, örgütsel iletişimi } \\
\text { ve performansı etkilemektedir. }\end{array}$ \\
\hline
\end{tabular}


İlgili literatürde, örgütsel bağlılığın işgören performansını etkilediği (Tablo 1), örgütsel bağlılığın iş tatminini etkilediği (Tablo 2) ve iş tatmininin işgören performansını etkilediği (Tablo 3) çalışmalar bulunmaktadır. Bu çalışmalardaki genel sonuçlar ve bu kavramlarla ilgili görüşler (Judge vd., 2001; Bayrak Kök, 2006; Altun, 2019) temelinde aşağıdaki hipotez geliştirilmiştir.

H4: Örgütsel bağlılık ile işgören performansı arasındaki ilişkide iş tatmininin aracılık rolü vardir.

\section{METODOLOJI}

$\mathrm{Bu}$ çalışmanın araştırma yöntemi, nicel araştırma yöntemi olarak belirlenmiştir. Araştırma türü olarak, ilişkisel (korelasyonel) araştırma seçilmiştir. Bu araştırma türüne ait veriler (veri toplama tekniği) anket tekniği ile toplanmıştır. Örnekleme yöntemi, kolayda örnekleme yöntemi olarak tercih edilmiştir (Tanrı̈ğen, 2012: 176; Aziz, 2014: 58-59). Bu bölümde araştırmanın amacı, önemi, kapsamı, sınırlılıkları, araştırmada kullanılan ölçekler ve verilerin analizi hakkında bilgiler verilmiştir.

\subsection{Araştırmanın Amacı ve Önemi}

Bu çalışmada, iş tatmininin örgütsel bağlılık ile işgören performansı arasındaki ilişkide aracılık rolünün belirlenmesi amaçlanmaktadır. $\mathrm{Bu}$ amaç kapsamında ilgili literatür incelendiğinde üniversite personeli üzerine bu üç kavramın birbiriyle yapıldığı bir araştırma tespit edilmemiştir. Özel sektör, turizm sektörü, hizmet sektörü, otomotiv sektörü ve eğitim alanı vb. sektörlerde bu kavramlar üzerine araştırmalar yapılmasına karşın üniversite personeli üzerine bir araştırma yapılmadığı görülmüştür. Örgütsel bağlılı̆̆ın işgören performansına, örgütsel bağlılı̆̆ın iş tatminine ve iş tatmininin işgören performansına etkisinin araştırılması hem yöneticiler hem de çalışanlar için büyük önem arz etmektedir. Bu açıdan üniversite personeli algılarının araştırılması ve bu araştırma için bir model önerilmesi çalışmanın önemini oluşturmaktadır.

\subsection{Araştırmanın Kapsamı ve Sınırlılıkları}

$\mathrm{Bu}$ araştırma sadece üniversitede çalışan idari personeli kapsamaktadır. Zaman, maliyet ve ulaşılabilirlik açısından araştırma sadece bir devlet üniversitesi ile sınırlandırılmıştır. Bu çalışmanın örneklemini, ilgili devlet üniversitesinin 2019-2020 eğitim-öğretim yılına ait 2793 idari personeli oluşturmaktadır. Araştırma için Süleyman Demirel Üniversitesi Rektörlüğü Sosyal ve Beşeri Bilimler Etik Kurul Başkanlığı'ndan etik kurul izni (22.10.2019 tarihli, 87432956/050.99/17617 sayılı ve Etik Kurul Onayı konulu) ve ilgili yerlerden izinler alınmıştır.

\subsection{Araştırmada Kullanılan Veri Toplama Araçları}

Bu bölümde örgütsel bağlılık ölçeği, işgören performansı ölçeği, iş tatmini ölçeği ve sosyodemografik özellikler bilgi formu hakkında bilgiler verilmiştir.

Örgütsel Bağlllık Ölçeği: İdari personele, kurumuna yönelik aidiyet düzeyinin belirlenmesi için örgütsel bağlllık ölçeği uygulanmıştır. Bu ölçek Allen ve Meyer tarafından geliştirilmiştir (Allen ve Meyer, 1990; Meyer ve Allen, 1991; Meyer, Allen ve Smith, 1993). Örgütsel bağlılık ölçeğinin Türkçe uyarlaması Baysal ve Paksoy (1999) tarafından yapılmıştır. Bu ölçek 18 ifade ve 3 boyuttan (duygusal bağlılık, devam bağlılığ1 ve normatif bağlılık) oluşmaktadır. Duygusal bağlılığa ait örnek bir ifade "çalışmakta olduğum kurumda zaman geçirmek beni 
mutlu eder", devam bağlılığına ait örnek bir ifade "şu anda kendi isteğimden ziyade mecburiyetten dolayı bu kuruluşta çalışıyorum" ve normatif bağlılığa ait örnek bir ifade "bu kurumda çalışmaya devam etmek için zorunluluk hissetmiyorum" şeklindedir. Bu ifadelere ait önem değerlerinin belirlenmesi için 5'li likert tipi (1: Kesinlikle Katılmıyorum, .. , 5: Kesinlikle Katılıyorum) kullanılmıştır.

İşgören Performansı Ölçeği: İdari personelin bireysel olarak performansının değerlendirilmesi amaciyla Kirkman ve Rosen'in (1999) geliştirmiş olduğu, Sigler ve Pearson'ın (2000) ilk kez uyguladığı ve Çöl'ün (2008) Türkçe'ye uyarladığı işgören performansı (bireysel performans) ölçeği kullanılmıştır. Ölçek dört ifade ve tek boyuttan oluşmaktadır. Bu ölçeğe ait örnek bir ifade "görevlerimi tam zamanında tamamlarım" şeklindedir. Bu ifadelere ait önem değerlerinin belirlenmesi için 5'li likert tipi (1: Hiçbir Zaman; 2: Nadiren; 3: Bazen; 4: Sık Sık; 5: Her Zaman) kullanılmıştır.

İş Tatmini Ölçeği: İdari personelin işinden ne derece memnun olduğunun belirlenmesi için Weiss, Dawis, England ve Lofquist'in (1967) geliştirmiş olduğu Baycan'ın (1985) Türkçe'ye uyarladığı Minnesota İş Tatmini Ölçeği kullanılmıştır. Ölçek 100 soruluk (uzun formu) ve 20 soruluk (kısa formu) olmak üzere iki formu vardır. Bu çalışmada ölçeğin 20 soruluk kısa formu tercih edilmiştir. Ölçekte bulunan 20 ifade 2 boyuttan (içsel tatmin ve dişsal tatmin) oluşmaktadır. İçsel tatmine ait örnek bir ifade "işimin beni her zaman meşgul etmesinden ..." ve dışsal tatmine ait örnek bir ifade "işimin yaptığım iş karşılığı aldığım ücretten ..." şeklindedir. Bu ifadelere ait önem değerlerinin belirlenmesi için 5'li likert tipi (1: Hiç Memnun Değilim, ... , 5: Çok Memnunum) kullanılmıştır.

Sosyo-Demografik Özellikler: Anketi cevaplayanların sosyo-demografik özelliklerinin belirlenmesi için cinsiyet, eğitim düzeyi, yaş, ücret (maaş), mevcut kurumda çalışma süresi, toplam çalışma süresi ve çalıştığ1 birim olmak üzere yedi ifadeden oluşan sorular yöneltilmiştir.

\subsection{Araştırmanın Modeli}

Örgütsel bağlılık ile işgören performansı arasındaki ilişkide iş tatmininin aracılık rolüne ait araştırma modeli Şekil 1'de gösterilmektedir.

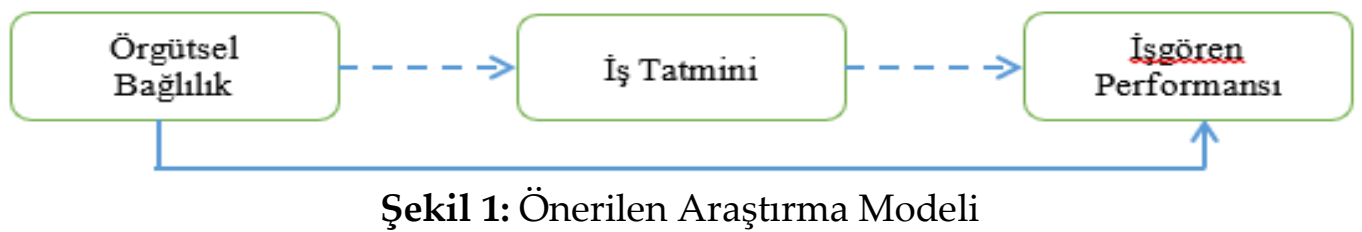

Şekil 2'de duygusal, devam ve normatif bağlılık ile işgören performansı arasındaki ilişkide içsel tatmin ve dişsal tatminin aracılık rolüne ait araştırma modeli gösterilmektedir.

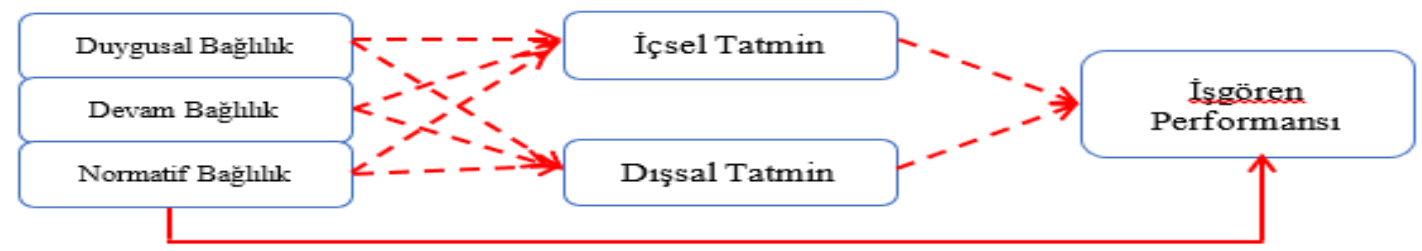

Şekil 2: Boyutlara Göre Önerilen Araştırma Modeli 


\subsection{Verilerin Analizi}

Anketler, araştırmacılar tarafından üniversite yerleşkesinde çalışan idari personele yüz yüze (bırak-topla şeklinde) uygulanmıştır. İdari personele 600 anket dağıtılmıştır. Daha sonra dağıtılan anketlerden 324'ü geri toplanmıştır. Toplanan anketler veri girişi yapılmadan önce anketi cevaplayanların anketteki kontrol sorusuna vermiş oldukları cevap incelenmiştir. İlk inceleme sonucunda 8 anket çıkarılmıştır. Daha sonra anketteki veriler Microsoft Excel 2020 'ye girilerek SPSS 26 programına aktarılmıştır. Ankete verilen cevapların okunarak verildiğinden emin olunması amacıyla soruların uç değerlerine bakılmıştır. İkinci inceleme sonucunda 36 anket daha çıkarılmıştır. Nihai olarak elde edilen 324 anketten 280 anket analiz için uygun görülmüştür. Bu çalışmada tanımlayıcı analizler (güvenirlik analizi, keşfedici faktör analizi (KFA), frekans, ortalama, standart sapma ve korelasyon analizi) SPSS 26 programında yapılmıştır. Ölçekler arasında etkinin belirlenmesi ve aracılık rolünün olup olmadığının tespit edilmesi için ise doğrulayıcı faktör analizleri (DFA) ve yol analizleri AMOS 24 programında yapılmıştır.

\section{BULGULAR}

\subsection{Güvenirlilik ve Geçerlilik}

Araştırmada kullanılan ölçeklerle ilgili analizlerin yapılabilmesi için ilk olarak güvenilir ve geçerli olup olmadığının tespit edilmesi gerekmektedir. Araştırma sorularının ve ölçeklerin güvenirliliği için güvenirlik katsayı değeri (Cronbach's Alpha; $\alpha$ ) hesaplanmaktadır. Güvenirlik katsayı değeri, ölçekteki ifadelerin iç tutarlılık durumunu göstermektedir (Matkar, 2012: 94). George ve Mallery'e (2019: 244) göre güvenirlik katsayı değeri 0,60'tan (sorgulanabilir) yüksek olması gerekmektedir. Araştırma sorularının ve ölçeklerin güvenirliliği için KFA ve DFA yapılmıştır. Ölçeklere uygulanan KFA'nın uygun olup olmadığının belirlenmesi için KMO (Kaiser Meyer Olkin Measure of Sampling Adequacy) ve Bartlett Küresellik Testi Yaklaşımı (Bartlett's Test of Sphericity Approx. Chi-Square) değeri incelenmektedir. Field'e (2005: 640) göre KMO değeri, 0,50-0,69 arasında "orta seviyede", 0,70-0,79 arasında "iyi", 0,80-0,89 arasında "çok iyi" ve 0,90 ve üstü "mükemmel" olarak kabul edilmektedir. KFA'nın kabul edilebilir seviyede olabilmesi için; KMO değerinin 0.60 'tan yüksek çıkması ve Bartlett Küresellik Testi Yaklaşımı değerinin ise 0,05'ten daha düşük çıkması gerekmektedir (Büyüköztürk, 2019: 126). Faktör analizi sonucu ifadelere yüklenen faktör yükü değerlerinin 0,30'un üstünde olması gerekmektedir (Scherer, Luther, Wiebe ve Adams, 1988: 766). Tablo 5'te örgütsel bağlılığa ait güvenirlilik katsayı değerleri ve KFA değerleri gösterilmektedir.

Tablo 5: Örgütsel Bağl1lı̆̆a Ait KFA Sonuçları

\begin{tabular}{|c|c|c|c|c|c|}
\hline Değişkenler & Madde Sayısı & $\begin{array}{c}\text { Faktör Yükü } \\
\text { Aralıkları }\end{array}$ & $\begin{array}{l}\text { Toplam } \\
\text { Öz Değer }\end{array}$ & $\begin{array}{c}\text { Faktörlerin } \\
\text { Varyansa Katkısı } \\
(\%)\end{array}$ & $\begin{array}{c}\text { Güvenirlik } \\
\text { Katsayı Değeri } \\
(\alpha)\end{array}$ \\
\hline Duygusal Bağlılık & 6 madde & $0,688-0,845$ & 5,301 & 35,338 & 0,894 \\
\hline Devam Bağlılı̆̆1 & 5 madde & $0,467-0,742$ & 2,093 & 13,950 & 0,690 \\
\hline Normatif Bağlılık & 4 madde & $0,504-0,690$ & 1,197 & 7,982 & 0,662 \\
\hline Örgütsel Bağlılık & 15 madde & $0,467-0,845$ & - & 57,270 & 0,844 \\
\hline
\end{tabular}


KFA sonucu; 15 ifadeden oluşan örgütsel bağlllı̆̆1 3 boyuta (duygusal bağlllık, devam bağlılığ1 ve normatif bağll1ık) dönüşerek varyansın \%57,27'sini açıkladığ1 tespit edilmiştir (KMO Değeri: 0,884; $X^{2} 280$ : 1633,466; sd: 105; p: 0.000). Devam bağlilı̆̆ına ait 1 maddenin ve normatif bağlılığa ait 2 maddenin faktör yükü değeri 0,30'dan düşük çıktığ 1 için analize dahil edilmemiştir. Diğer ifadelere ait faktör yükleri 0,30'dan yüksek çıkmıştır. Örgütsel bağlılığa ait 15 ifadenin faktör yükleri “0,467-0,845” arasındaki değerleri almıştır. Örgütsel bağlılığa ait ( $\mathrm{n}=280$ için $\alpha=0,844$ ve $\mathrm{k}=15$ ) faktörlerin güvenirlik katsayı değeri; duygusal bağlılıkta 0.894 ( $\mathrm{n}=280$ için $\alpha=0,894$ ve $\mathrm{k}=6$ ), devam bağlılığında 0,690 ( $\mathrm{n}=280$ için $\alpha=0,690$ ve $\mathrm{k}=5$ ) ve normatif bağlılıkta 0,662 ( $\mathrm{n}=280$ için $\alpha=0,662$ ve $\mathrm{k}=4$ ) şeklinde elde edilmiştir.

DFA'nın kabul edilebilirliği için ki-kare (Chi-Square; X2), yaklaşık hataların ortalama karekökü (Root Mean Square Error of Approximation; RMSEA), karşılaştırmalı uyum indeksi (Comparative Fit Index; CFI), iyilik uyum indeksi (Goodness of Fit Index; GFI) ve düzeltilmiş iyilik uyum indeksi (Adjusted Goodness of Fit Index; AGFI) değerlerine bakılmaktadır. Bu değerlerin iyi uyum ve kabul edilebilir aralıkları Tablo 6' da verilmektedir (Schumacker ve Lomax, 2004: 82; Byrne, 2016; Gürbüz ve Şahin, 2018: 345).

Tablo 6: DFA İçin İyi Uyum ve Kabul Edilebilir Değerleri

\begin{tabular}{|c|c|c|}
\hline Değişkenler & $\begin{array}{c}\text { İyi Uyum } \\
\text { Değerleri }\end{array}$ & $\begin{array}{c}\text { Kabul Edilebilir } \\
\text { Değerler }\end{array}$ \\
\hline $\mathrm{X}^{2}$ & \multicolumn{2}{|c|}{$\mathrm{p} \leq 0.05$} \\
\hline $\mathrm{X}^{2} / \mathrm{sd}$ & $1 \leq \mathrm{X}^{2} / \mathrm{sd}<3$ & $3 \leq \mathrm{X}^{2} / \mathrm{sd} \leq 5$ \\
\hline $\mathrm{RMSEA}$ & $\leq 0,05$ & $\leq 0,08$ \\
\hline CFI & $\geq 0,95$ & $\geq 0,85$ \\
\hline GFI & $\geq 0,95$ & $\geq 0,85$ \\
\hline AGFI & $\geq 0,95$ & $\geq 0,80$ \\
\hline
\end{tabular}

Kaynak: Schumacker ve Lomax, 2004: 82; Byrne, 2016; Gürbüz ve Şahin, 2018: 345.

Örgütsel bağlılığa ait DFA sonuçları Şekil 3’te gösterilmiştir.

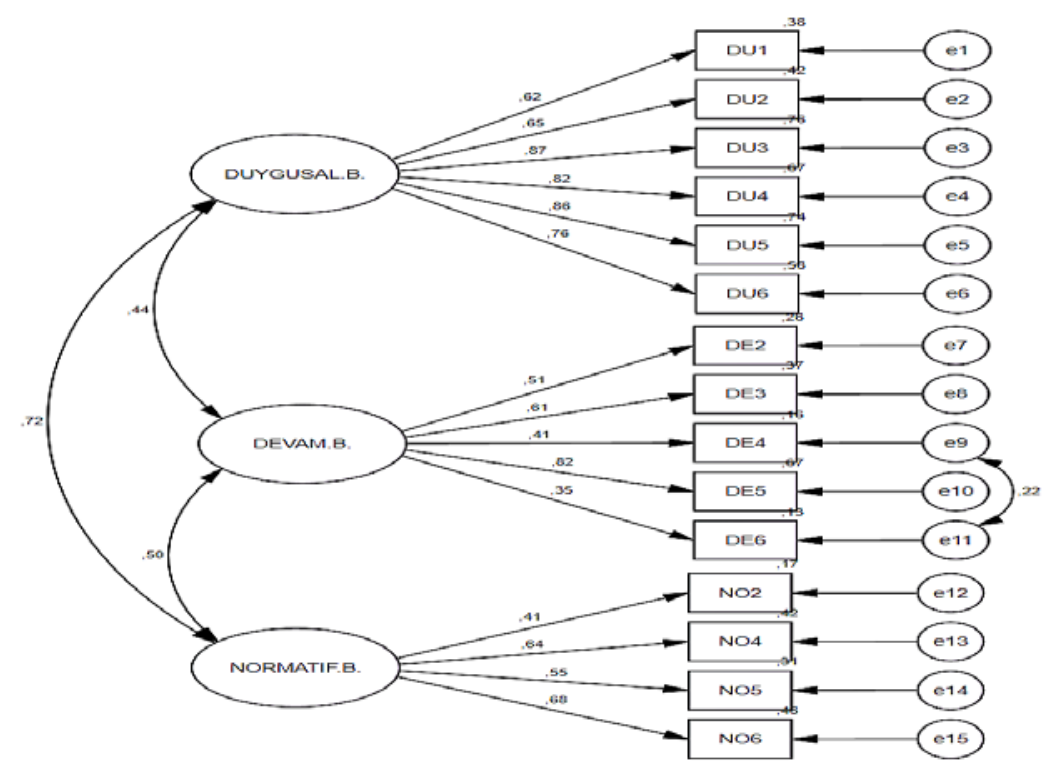

Şekil 3: Örgütsel Bağlılığa Ait DFA Sonuçları

Örgütsel bağlılığa birinci seviye DFA uygulanmıştır. Uygulanan DFA'nın kabul edilebilir değerler içinde yer alması için iki aşamalı bir model geliştirilmiştir. Model a'nın değerleri 
$\left(X^{2} 87=226,156 ; X^{2} / s d=2,599 ; p \leq 0,05 ; R M S E A=0,076 ; C F I=0,911 ; G F I=0,900 ; A G F I=0,862\right.$ kabul edilebilir değerin altında çıkmıştır. Model b için devam bağlılığındaki DE4 ve DE6 ifadeleri arasında korelasyon kurulmuştur. Bu modelin değerleri $\left(X^{2} 86=213,423 ; X^{2} / s d=2,482 ; p \leq 0,05\right.$; RMSEA=0,073; CFI=0,918; GFI=0,908; $A G F I=0,871$ ) iyi uyum ve kabul edilebilir değerler içinde çıkmıştır. Bu değerlere göre örgütsel bağlılığın 3 boyuttan oluştuğu kabul edilmiştir. Tablo 7'de işgören performansına ait güvenirlilik katsayı değerleri ve KFA değerleri gösterilmektedir.

Tablo 7: İşgören Performansına Ait KFA Sonuçları

\begin{tabular}{|c|c|c|c|c|c|}
\hline & $\begin{array}{c}\text { Madde } \\
\text { Sayısı }\end{array}$ & $\begin{array}{c}\text { Faktör Yükü } \\
\text { Aralıkları }\end{array}$ & $\begin{array}{c}\text { Toplam Öz } \\
\text { Değer }\end{array}$ & $\begin{array}{c}\text { Faktörlerin } \\
\text { Varyansa Katkısı } \\
(\%)\end{array}$ & $\begin{array}{c}\text { Güvenirlik } \\
\text { Katsayı Değeri } \\
(\boldsymbol{\alpha})\end{array}$ \\
\hline $\begin{array}{c}\text { İşgören } \\
\text { Performansı }\end{array}$ & 4 madde & $0,776-0,837$ & 2,588 & 64,710 & 0,817 \\
\hline \multicolumn{7}{|c|}{ KMO Değeri: 0,$792 ;$ Ki-Kare Değeri $\left(\mathbf{X}^{2}\right): 373,622 ;$ sd: $6 ;$ p: 0,000} \\
\hline
\end{tabular}

KFA sonucu; 4 ifadeden oluşan işgören performansının tek boyuta dönüşerek varyansın \%64,71'ini açıkladığı tespit edilmiştir (KMO Değeri: 0,792; $X^{2} 280: 373,622 ;$ sd: 6; p: 0,000). Tüm ifadelere ait faktör yükleri 0,30'dan yüksek çıkmıştır. İşgören performansına ait 4 ifadenin faktör yükleri "0,776-0,837" arasındaki değerleri almıştır. İşgören performansına ait güvenirlik katsayı değeri 0,817 ( $\mathrm{n}=280$ için $\alpha=0,817$ ve $\mathrm{k}=4$ ) şeklinde elde edilmiştir. İşgören performansına ait DFA sonuçları Şekil 4'te gösterilmiştir.

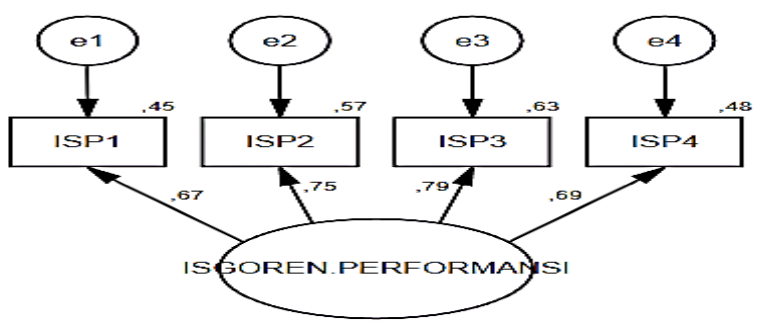

Şekil 4: İşgören Performansına Ait DFA Sonuçları

İşgören performansına birinci seviye tek faktörlü DFA uygulanmıştır. Uygulanan DFA'nın kabul edilebilir değerler içinde yer alması için tek bir model geliştirilmiştir. Modelin değerleri $\left(X^{2}{ }_{2}=4,855 ; X^{2} / s d=2,428 ; p \geq 0,05 ; R M S E A=0,072 ; C F I=0,992 ; G F I=0,992 ; A G F I=0,959\right)$ iyi uyum ve kabul edilebilir değerler içinde çıkmıştır. Birinci seviye tek faktörlü doğrulayıcı analizlerde p değerinin 0,05'ten yüksek çıkması gerekmektedir (Özdamar, 2017: 238). Bu değerlere göre işgören performansının tek boyuttan oluştuğu kabul edilmiştir. Tablo 8' de iş tatminine ait güvenirlilik katsayı değerleri ve KFA değerleri gösterilmektedir.

Tablo 8: İş Tatminine Ait KFA Sonuçları

\begin{tabular}{|c|c|c|c|c|c|}
\hline Değişkenler & $\begin{array}{c}\text { Madde } \\
\text { Sayısı }\end{array}$ & $\begin{array}{c}\text { Faktör Yükü } \\
\text { Aralıkları }\end{array}$ & $\begin{array}{c}\text { Toplam } \\
\text { Öz Değer }\end{array}$ & $\begin{array}{c}\text { Faktörlerin } \\
\text { Varyansa Katkısı } \\
(\mathbf{\%})\end{array}$ & $\begin{array}{c}\text { Güvenirlik } \\
\text { Katsayı Değeri } \\
(\boldsymbol{\alpha})\end{array}$ \\
\hline İçsel Tatmin & 9 madde & $0,542-0,728$ & 6,241 & 39,004 & 0,839 \\
\hline Dışsal Tatmin & 7 madde & $0,551-0,882$ & 1,584 & 9,901 & 0,873 \\
\hline İş Tatmini & 16 madde & $0,542-0,882$ & - & 48,905 & 0,898 \\
\hline
\end{tabular}


KFA sonucu; 16 ifadeden oluşan iş tatmininin 2 boyuta (içsel tatmin ve dişsal tatmin) dönüşerek varyansın \%48,91'ini açıkladığı tespit edilmiştir (KMO Değeri: 0,895; X²80: 1764,464; sd: 120; p: 0,000). İçsel tatmine ait 3 maddenin ve dişsal tatmine ait 1 maddenin faktör yükü değeri 0,30 ' dan düşük çıktığ faktör yükleri 0,30 'dan yüksek çıkmıştır. İş tatminine ait 16 ifadenin faktör yükleri “ $0,542-$ 0,882" arasındaki değerleri almıştır. İş tatminine ait ( $\mathrm{n}=280$ için $\alpha=0,898$ ve $\mathrm{k}=16$ ) faktörlerin güvenirlik katsayı değeri; içsel tatminde 0.839 ( $\mathrm{n}=280$ için $\alpha=0,839$ ve $\mathrm{k}=9$ ) ve dışsal tatminde 0,873 ( $\mathrm{n}=280$ için $\alpha=0,873$ ve $\mathrm{k}=7$ ) şeklinde elde edilmiştir. İş tatminine ait DFA sonuçları Şekil 5 'te gösterilmiştir.

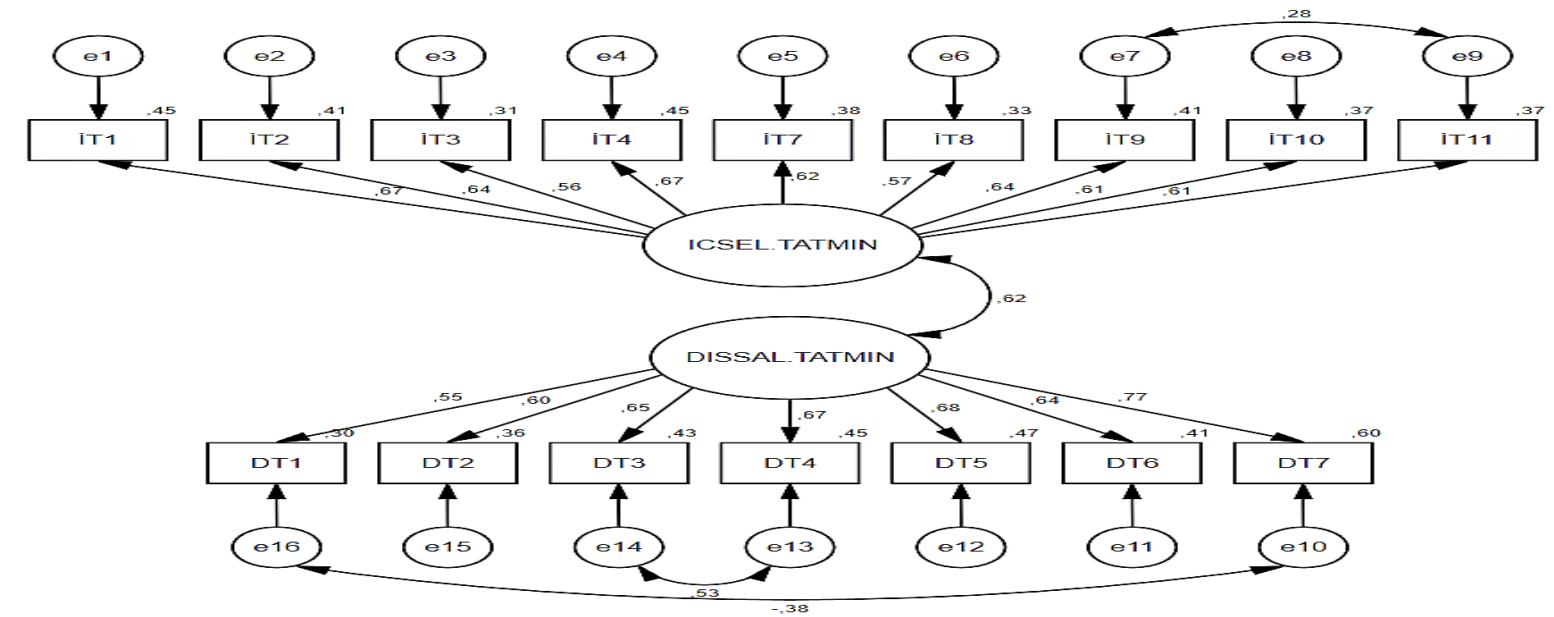

Şekil 5: İş Tatminine Ait DFA Sonuçları

İş tatminine birinci seviye DFA uygulanmıştır. Uygulanan DFA'nın kabul edilebilir değerler içinde yer alması için dört aşamalı bir model geliştirilmiştir. Model a'nın değerleri $\left(X^{2}{ }_{120}=427,257 ; X^{2} / \mathrm{sd}=3,560 ; \mathrm{p} \leq 0,05 ; \mathrm{RMSEA}=0,096 ; \mathrm{CFI}=0,86 ; \mathrm{GFI}=0,838 ; \mathrm{AGFI}=0,794\right)$ kabul edilebilir değerin altında çıkmıştır. Model b için dışsal tatmindeki DT3 ve DT4 ifadeleri arasında korelasyon kurulmuştur. $\mathrm{Bu}$ modelin değerleri de $\left(\mathrm{X}^{2}{ }_{11}=377,311 ; \mathrm{X}^{2} / \mathrm{sd}=3,171\right.$; $\mathrm{p} \leq 0,05 ; \mathrm{RMSEA}=0,088 ; \mathrm{CFI}=0,882 ; \mathrm{GFI}=0,857$; $\mathrm{AGFI}=0,816$ ) kabul edilebilir değerlerin altında çıkmıştır. Model c için içsel tatmindeki İT9 ve İT11 ifadeleri arasında korelasyon kurulmuştur. $\mathrm{Bu}$ modelin değerleri de $\left(\mathrm{X}^{2}{ }_{118}=355,303 ; \mathrm{X}^{2} / \mathrm{sd}=3,011 ; \mathrm{p} \leq 0,05 ; \mathrm{RMSEA}=0,085\right.$; $\mathrm{CFI}=0,892 ; \mathrm{GFI}=0,867$; AGFI=0,828) kabul edilebilir değerlerin altında çıkmıştır. Model d için dişsal tatmindeki DT1 ve DT7 ifadeleri arasında korelasyon kurulmuştur. Bu modelin değerleri $\quad\left(X^{2}{ }_{117}=332,085 ; \quad X^{2} / s d=2,838 ; \quad p \leq 0,05 ; \quad R M S E A=0,081 ; \quad C F I=0,902 ; \quad G F I=0,873\right.$; AGFI=0,834) iyi uyum ve kabul edilebilir değerler içinde çıkmıştır. Bu modelde elde edilen RMSEA değeri kabul edilebilir değerin üstünde çıkmasına karşın Steiger'e göre RMSEA değeri 0,08-0,10 arasında olursa model zayıf olarak kabul edilebilmektedir (Tomer ve Pugesek, 2003: 133). Bu değerlere göre iş tatmininin 2 boyuttan oluştuğu kabul edilmiştir.

\subsection{Tanımlayıcı Analizler}

İdari personelin cinsiyet, eğitim düzeyi, yaş aralığı (yıl), ücret (maaş; €), mevcut kurumda çalışma süresi (yıl), toplam çalışma süresi (yıl) ve çalıştığı birimden oluşan sosyo-demografik özellikleri Tablo 9'da gösterilmektedir. 
Tablo 9: İdari Personelin Sosyo-Demografik Özellikleri

\begin{tabular}{|c|c|c|c|c|c|c|c|}
\hline \multicolumn{2}{|c|}{ Değişkenler } & $\mathbf{n}$ & $\%$ & \multicolumn{2}{|c|}{ Değişkenler } & $\mathbf{n}$ & $\%$ \\
\hline \multirow{3}{*}{ Cinsiyet } & Kadın & 118 & 42,1 & \multirow{5}{*}{$\begin{array}{c}\text { Mevcut } \\
\text { Kurumda } \\
\text { Çalışma Süresi }\end{array}$} & $\leq 3$ yil & 27 & 9,6 \\
\hline & Erkek & 161 & 57,5 & & 4-7 yıl & 82 & 29,3 \\
\hline & Cevapsiz & 1 & 0,40 & & 8-11 yil & 39 & 13,9 \\
\hline & & & & & $\geq 12$ yil & 127 & 45,4 \\
\hline \multirow{5}{*}{ Eğitim Düzeyi } & Ortaokul-Lise & 54 & 19,3 & & Cevapsiz & 5 & 1,8 \\
\hline & Önlisans & 54 & 19,3 & & & & \\
\hline & Lisans & 131 & 46,8 & \multirow{5}{*}{$\begin{array}{c}\text { Toplam Çalışma } \\
\text { Süresi }\end{array}$} & $\leq 3 \mathrm{y} 1 \mathrm{l}$ & 14 & 5,00 \\
\hline & Yüksek Lisans & 38 & 13,6 & & 4-7 y1l & 39 & 13,9 \\
\hline & Doktora & 3 & 1,10 & & 8-11 yil & 46 & 16,4 \\
\hline & & & & & $\geq 12 \mathrm{yll}$ & 180 & 64,3 \\
\hline \multirow{4}{*}{ Yaş Aralı̆̆1 } & $\leq 40$ yaş & 83 & 29,6 & & Cevapsiz & 1 & 0,40 \\
\hline & $\geq 41$ yaş & 64 & 22,9 & & & & \\
\hline & Cevapsiz & 133 & 47,5 & \multirow{5}{*}{ Çalıştı̆̆ı Birim } & Rektörlük & 106 & 37,7 \\
\hline & Ort. \pm Std. Sp. & 39,3 & 8,493 & & $\begin{array}{c}\text { Meslek } \\
\text { Yüksekokulu }\end{array}$ & 12 & 4,3 \\
\hline & & & & & Yüksekokul-Fakülte & 102 & 36.5 \\
\hline \multirow{6}{*}{$\begin{array}{l}\text { Ücret } \\
\text { (Maaş) }\end{array}$} & $\leq 2500 €$ & 74 & 26,4 & & Enstitü & 17 & 6,1 \\
\hline & 2501-3500 € & 30 & 10,7 & & Diğer Bölümler & 43 & 15,4 \\
\hline & 3501-4500 & 71 & 25,4 & & Toplam & 280 & 100 \\
\hline & $4501-5500$ モ & 35 & 12,5 & & & & \\
\hline & $\geq 5501$ € & 44 & 15,7 & & & & \\
\hline & Cevapsiz & 26 & 9,3 & & & & \\
\hline
\end{tabular}

Araştırmaya katılanların \%57,5'i erkek ve \%42,1'i kadındır. İdari personelin eğitim düzeyi; $\% 19,3$ 'ü ortaokul-lise, \%19,3'ü önlisans, \%46,8'i lisans ve \%14,7'si lisansüstü şeklinde dağılmaktadır. Araştırmaya katılanların yaş aralığı 22-60 arasındadır. Yaş ortalaması yaklaşık 40'tır $(39,37 \pm 8,493)$. \%29,6's1 40 yaş altında ve \%22,9'u 40 yaş üstündedir. Araştırmaya katılanların \%47,5'i bu soruyu boş bırakmıştır. İdari personelin almış oldukları ücretin dağılımı; \%26,4'ü 2500 €’nin altında, \%10,7'si 2501-3500 £ arası, \%25,4'ü 3501-4500 £ arası, \%12,5'i 4501-5500 ₹ arası ve \%15,7'si 5501 €’nin üstünde şeklindedir. Araştırmaya katılanların \%9,3'ü bu soruyu cevaplamamıştır. Mevcut kurumda çalışma süresinin dağılımı; $\% 9,6$ 's 1-3 yıl arası, \%29,3'ü 4-7 yıl arası, \%13,9'u 8-11 yıl arası ve \%45,4'ü 12 yıl ve üstü şeklindedir. Toplam çalışma süresinin dağılımı; \%5'i 1-3 yıl arası, \%13,9'u 4-7 yıl arası, $\% 16,4^{\prime}$ ü 8-11 yıl arası ve \%64,3'ü 12 yıl ve üstü şeklindedir. Personelin mevcut kurumda çalışma süresine ve toplam çalışma süresine bakıldığına iş devir hızının düşük olduğu görülmektedir. İdari personelin çalıştıkları birimlerin dağılımı; \%37,7'si rektörlük, \%4,3'ü meslek yüksekokulu, \%36,5'i yüksekokul-fakülte, \%6,1'i enstitü ve \%15,4'ü diğer bölümler (hastane ve döner sermaye) şeklindedir.

Korelasyon analizi, ölçeklerin ve boyutların aralarındaki ilişki seviyesini (r) göstermektedir. Ural ve Kılıç'a (2013: 244) göre ilişki seviyesinin değerleri; 0,00-0,29 arasında ise zayıf/düşük düzeyde ilişki $(0,00 \leq \mathrm{r} \leq 0,29), 0,30-0,64$ arasında ise orta düzeyde ilişki $(0,30 \leq \mathrm{r} \leq 0,64), 0,65$ 0,84 arasında ise kuvvetli/yüksek düzeyde ilişki $(0,65 \leq \mathrm{r} \leq 0,84)$ ve $0,85-1,00$ arasında ise çok kuvvetli/çok yüksek düzeyde bir ilişki olduğu $(0,85 \leq \mathrm{r} \leq 1,00)$ şeklindedir. Tablo $10^{\prime}$ da örgütsel bağlılık $(3,464 \pm 0,802)$, işgören performansı $(4,489 \pm 0,605)$ ve iş tatmini $(3,779 \pm 0,772)$ arasındaki ilişki gösterilmektedir. 
Tablo 10: Ölçekler ve Boyutlar Arasındaki Korelasyon, Ortalama ve Standart Sapma Değerleri

\begin{tabular}{|c|c|c|c|c|c|c|c|c|c|}
\hline Değișkenler & İT & ÖB & İP & ICT & DT & DUB & DEB & NB & IP \\
\hline İT & 1 & & & & & & & & \\
\hline ÖB & $0,473^{* *}$ & 1 & & & & & & & \\
\hline İP & $0,241^{* *}$ & $0,335^{* *}$ & 1 & & & & & & \\
\hline ICT & & & & 1 & & & & & \\
\hline DT & & & & $0,562^{* *}$ & 1 & & & & \\
\hline DUB & & & & $0,497^{* *}$ & $0,567^{* *}$ & 1 & & & \\
\hline DEB & & & & $0,149^{*}$ & 0,004 & $0,207^{* *}$ & 1 & & \\
\hline NB & & & & $0,423^{* *}$ & $0,405^{* *}$ & $0,481^{* *}$ & $0,277^{* *}$ & 1 & \\
\hline IP & & & & $0,293^{* *}$ & $0,144^{*}$ & $0,333^{* *}$ & $0,219^{* *}$ & $0,251^{* *}$ & 1 \\
\hline Ortalama & 3,779 & 3,464 & 4,489 & 4,032 & 3,511 & 3,871 & 3,014 & 3,539 & 4,489 \\
\hline Standart Sapma & 0,772 & 0,802 & 0,605 & 0,700 & 0,987 & 0,918 & 1,026 & 0,968 & 0,605 \\
\hline$* * *$ \\
\hline
\end{tabular}

(İş Tatmini: İT; Örgütsel Bağlllık: ÖB; İşgören Performansı: İ; İçsel Tatmin: İCT; Dışsal Tatmin: DT; Duygusal Bağllık: DUB; Devam Bağllı̆̆ı: DEB; Normatif Bağlılık: NB)

İş tatmini ile örgütsel bağlılık arasında anlamlı $(\mathrm{p} \leq 0,01)$ ve orta düzeyde bir ilişki $(\mathrm{r}=0,473)$ vardır. İş tatmini ile işgören performansı arasında anlamlı $(\mathrm{p} \leq 0,01)$ ve düşük bir ilişki $(\mathrm{r}=0,241)$ vardır. İşgören performansı ile örgütsel bağlılık arasında anlamlı $(\mathrm{p} \leq 0.01)$ ve orta düzeyde bir ilişki $(\mathrm{r}=0,335)$ vardır. İş tatmini, örgütsel bağlılık ve işgören performansı değişkenleri arasında pozitif yönlü bir ilişkinin olduğu görülmektedir. İçsel tatmin $(4,032 \pm 0,700)$, dişsal tatmin $(3,511 \pm 0,987)$, duygusal bağlılık $(3,871 \pm 0,918)$, devam bağl1lı̆̆ $(3,014 \pm 1,026)$, normatif bağl1lık $(3,539 \pm 0,968)$ ve işgören performansı arasındaki ilişki incelendiğinde sadece dişsal tatmin ile devam bağlllı̆̆ edilememiştir $(p \geq 0,05)$. İçsel tatmin ile dışsal tatmin arasında anlamlı $(p \leq 0,01)$ ve orta düzeyde bir ilişki $(\mathrm{r}=0,562)$ vardır. İçsel tatmin ile duygusal bağlılık arasında anlamlı $(\mathrm{p} \leq 0,01)$ ve orta düzeyde bir ilişki $(r=0,497)$ vardır. İçsel tatmin ile devam bağlılığı arasında anlamlı $(\mathrm{p} \leq 0,05)$ ve düşük bir ilişki $(\mathrm{r}=0,149)$ vardır. İçsel tatmin ile normatif bağlılık arasında anlamlı $(\mathrm{p} \leq 0,01)$ ve orta düzeyde bir ilişki $(\mathrm{r}=0,423)$ vardır. İçsel tatmin ile işgören performansı arasında anlamlı $(p \leq 0,01)$ ve düşük bir ilişki $(r=0,293)$ vardır. Dışsal tatmin ile duygusal bağlılık arasında anlamlı $(\mathrm{p} \leq 0,01)$ ve orta düzeyde bir ilişki $(\mathrm{r}=0,567)$ vardır. Dışsal tatmin ile normatif bağlılık arasında anlamlı $(\mathrm{p} \leq 0,01)$ ve orta düzeyde bir ilişki $(\mathrm{r}=0,405)$ vardır. Dışsal tatmin ile işgören performansı arasında anlamlı $(\mathrm{p} \leq 0,05)$ ve düşük bir ilişki $(\mathrm{r}=0,144)$ vardır. Duygusal bağlılık ile devam bağlılığı arasında anlamlı $(\mathrm{p} \leq 0,01)$ ve düşük bir ilişki $(\mathrm{r}=0,207)$ vardır. Duygusal bağlılık ile normatif bağlılık arasında anlamlı $(p \leq 0,01)$ ve orta düzeyde bir ilişki $(r=0,481)$ vardır. Duygusal bağlılık ile işgören performansı arasında anlamlı $(p \leq 0,01)$ ve orta düzeyde bir ilişki $(r=0,333)$ vardır. Devam bağlılığı ile normatif bağlılık arasında anlamlı $(\mathrm{p} \leq 0,01)$ ve düşük bir ilişki $(\mathrm{r}=0,277)$ vardır. Devam bağlılığ 1 ile işgören performansı arasında anlamlı $(\mathrm{p} \leq 0,01)$ ve düşük bir ilişki $(\mathrm{r}=0.219)$ vardır. Normatif bağlılık ile işgören performansı arasında anlamlı $(\mathrm{p} \leq 0,01)$ ve düşük bir ilişki $(\mathrm{r}=0,251)$ vardır. İçsel tatmin ile dişsal tatmin, duygusal bağlılık, devam bağlılığı, normatif bağlılık ve işgören performansı arasında pozitif yönlü bir ilişki vardır. Dışsal tatmin ile içsel tatmin, duygusal bağlılık, normatif bağlılık ve işgören performansı arasında pozitif yönlü bir ilişki vardır. 


\subsection{Aracılık Rolünün Belirlenmesi İçin Yol Modeli}

Baron ve Kenny (1986: 1173-1182), en az üç değişkenden oluşan modellerde aracılık rolünün belirlenmesi için üç aşamalı bir çözüm önerisinde bulunmuştur. Aşamalara geçmeden önce önerilen modelin bağımsız değişkeni (örgütsel bağlılık), bağımlı değişkeni (işgören performansı) ve aracı değişkeni (iş tatmini) belirlenmelidir. Bu araştırma için önerilen model Şekil 1 ve Şekil 2'de gösterilmiştir. Daha sonra çözüm aşamalarını test etmek amacıyla dört model oluşturulmalıdır. Birinci model Şekil 6'daki gibi bağımsız değişken (örgütsel bağlılık) ile bağımlı değişken (işgören performansı) arasındaki etkiyi gösteren bir yol modelidir. İkinci model Şekil 7'deki gibi bağımsız değişken (örgütsel bağlılık) ile aracı değişken (iş tatmini) arasındaki etkiyi gösteren bir yol modelidir. Üçüncü model Şekil 8'deki araci değişken (iş tatmini) ile bağımlı değişken (işgören performansı) arasındaki etkiyi gösteren bir yol modelidir. Dördüncü model Şekil 9' daki gibi bağımsız değişkenin (örgütsel bağlılık), bağımlı değişkenin (işgören performansı) ve aracı değişkenin (iş tatmini) arasındaki etkiyi gösteren bir yol modelidir. Oluşturulan bu modeller temelinde çözümün üç aşaması; (a) birinci modelde bağımsız değişken, bağımlı değişkeni anlamlı bir şekilde etkilemeli; (b) ikinci modelde bağımsız değişken, aracı değişkeni ve aracı değişken, bağımlı değişkeni anlamlı bir şekilde etkilemeli; (c) ikinci modelde ya bağımsız değişken bağımlı değişkeni ilk modele oranla anlamlı ama daha düşük seviyede etkilemeli ya da bağımsız değişkenin bağımlı değişkene etkisinin anlamsız olması şeklindedir. Ĕger bu üç aşama başarıyla gerçekleşirse aracılık rolünden bahsedilmektedir. İlk modele oranla ikinci modeldeki bağımsız değişkenin bağımlı değişkeni etkileme düzeyi anlamlı bir şekilde düşerse aracı değişkenin "kısmi aracılık" rolünden bahsedilir. İkinci modelde bağımsız değişkenin bağımlı değişkeni etkilemediği sonucu elde edilirse aracı değişkenin "tam aracılık" rolünden bahsedilir. Eğer bu iki durumda gerçekleşmezse aracı değişkenin "aracılık etkisi olmadığı" sonucuna ulaşılır. Birinci model, örgütsel bağlılık ile işgören performansı arasındaki etkiyi gösteren bir yol modeli Şekil 6’ da yer verilmiştir.

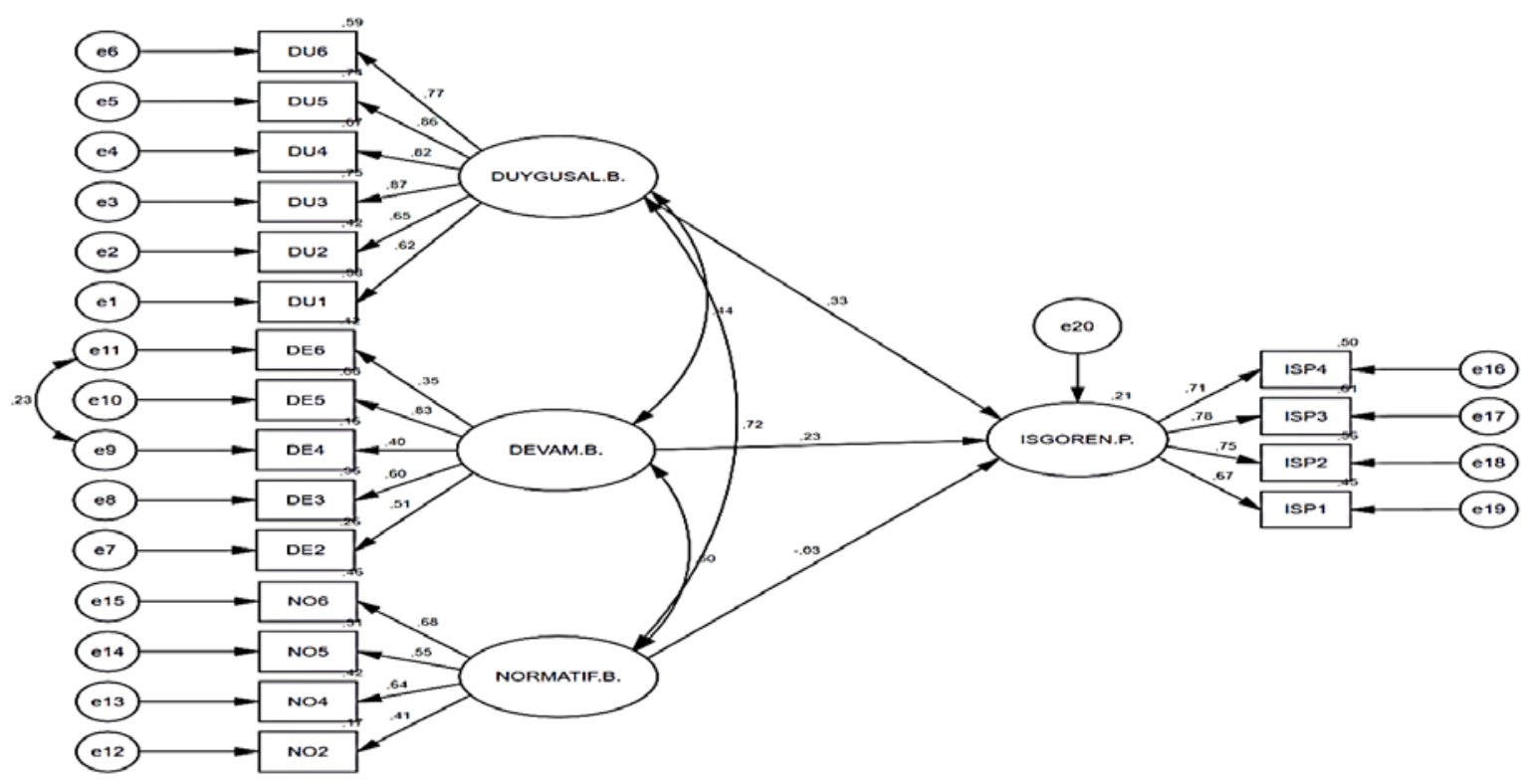

Şekil 6: Aracılık Rolü İçin Önerilen Modelin Yol Analizi (Aşama-I) 
Örgütsel bağlılığın (bağımsız değişken), işgören performansını (bağımlı değişken) etkileme durumuyla ilgili yol analizi yapılmıştır. Yol analizi için önerilen modelin değeri $\left(X^{2}{ }_{145}=298,937 ; X^{2} / s d=2,062 ; p \leq 0,05 ; R M S E A=0,062 ; C F I=0,923 ; \quad G F I=0,900 ; A G F I=0,868\right)$ iyi uyum ve kabul edilebilir değerler içinde çıkmıştır. Örgütsel bağlılığın işgören performansını etkileme durumuna Tablo 11'de yer verilmiştir.

Tablo 11: Örgütsel Bağlılığın İsgören Performansını Etkileme Durumu

\begin{tabular}{|c|c|c|c|}
\hline Bağımsız Değişken & Etki Yönü & Bağımlı Değişken & Standardize Regresyon Değeri $(\beta)$ \\
\hline Duygusal Bağllilk & & İşgören Performans1 & $0,334^{* *}$ \\
\hline Devam Bağllı̆ı̆̆1 & $\longrightarrow$ & İşgören Performansı & $0,230^{*}$ \\
\hline Normatif Bağl1lık & & İşgören Performansı & $-0,030$ \\
\hline
\end{tabular}

Duygusal bağlılık $(\beta=0,334 ; \quad p \leq 0,01)$ ve devam bağlllı̆̆1 $(\beta=0,230 ; \quad p \leq 0,05)$, işgören performansını anlamlı ve pozitif yönlü etkilemektedir. Bu sonuçlara göre H1a hipotezi (duygusal bağlılık, işgören performansını pozitif yönlü etkilemektedir) ve H1b hipotezi (devam bağlılığı, işgören performansını pozitif yönlü etkilemektedir) kabul edilmiştir. Normatif bağlılık $(\beta=-0,030 ; p \geq 0,05)$, işgören performansı üzerinde anlamlı bir etkisi yoktur. Elde edilen bu sonuca göre H1c hipotezi (normatif bağlılık, işgören performansını pozitif yönlü etkilemektedir) reddedilmiştir. Önerilen hipotezlerin test edilmesi sonucu H1 hipotezi (örgütsel bağlılık, işgören performansını pozitif yönlü etkilemektedir) kısmen kabul edilmiştir. İkinci model, örgütsel bağlllık ile iş tatmini arasındaki etkiyi gösteren bir yol modeli Şekil 7'de gösterilmektedir.

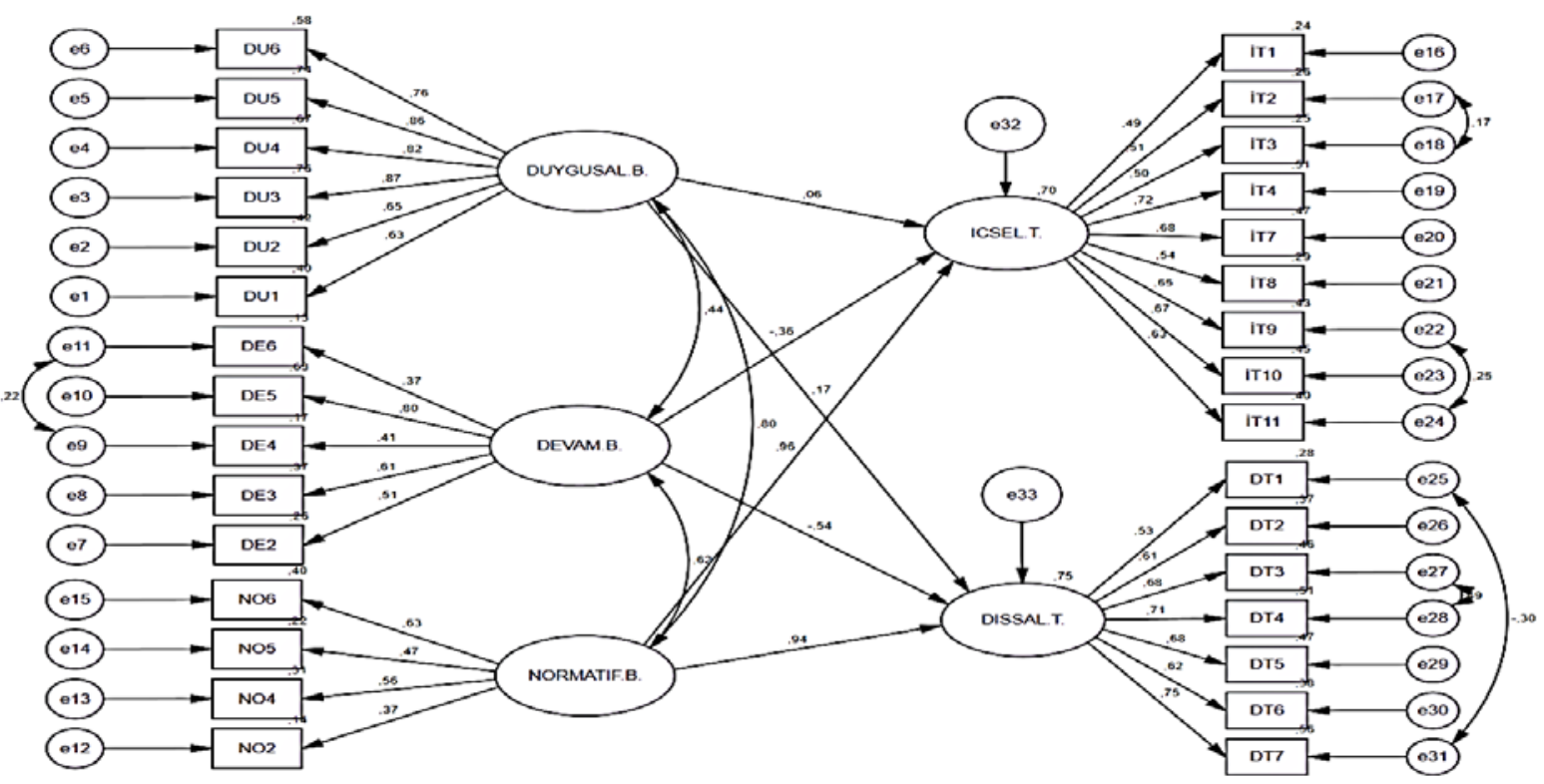

Şekil 7: Aracılık Rolü İçin Önerilen Modelin Yol Analizi (Aşama-I)

Örgütsel bağlılı̆̆ın (bağımsız değişken), iş tatminini (aracı değişken) etkileme durumuyla ilgili yol analizi yapılmıştır. Uygulanan yol analizinin kabul edilebilir değerler içinde yer alması için iki aşamalı bir model geliştirilmiştir. Model a'nın değerleri $\left(X^{2}{ }_{421}=857,935\right.$; $\mathrm{X}^{2} / \mathrm{sd}=2,038 ; \mathrm{p} \leq 0,05 ; \quad \mathrm{RMSEA}=0,061 ; \mathrm{CFI}=0,877 ; \mathrm{GFI}=0,836$; AGFI=0,807) kabul edilebilir değerin altında çıkmıştır. Model $b$ için içsel tatmindeki DT1 ve DT2 ifadeleri arasında korelasyon kurulmuştur. $\mathrm{Bu}$ modelin değerleri $\left(X^{2}{ }_{420}=821,637 ; \quad X^{2} / \mathrm{sd}=1,956 ; \mathrm{p} \leq 0,05\right.$; RMSEA=0,059; $C F I=0,887 ; \mathrm{GFI}=0,842 ; \mathrm{AGFI}=0,813$ ) iyi uyum ve kabul edilebilir değerler 
içinde çıkmıştır. Örgütsel bağllığın iş tatminini etkileme durumuna Tablo 12 'de yer verilmiştir.

Tablo 12: Örgütsel Bağlılığın İş Tatminini Etkileme Durumu

\begin{tabular}{|c|c|c|c|}
\hline Bağımsız Değişken & Etki Yönü & Aracı Değişken & Standardize Regresyon Değeri $(\beta)$ \\
\hline Duygusal Bağlılık & & İçsel Tatmin & 0,042 \\
\hline Devam Bağlılığ & $\longrightarrow$ & İçsel Tatmin & $0,994^{* * *}$ \\
\hline Normatif Bağlllık & $\longrightarrow$ & İçsel Tatmin & $-0,382^{* *}$ \\
\hline Duygusal Bağlılık & $\longrightarrow$ & Dişsal Tatmin & $-0,552^{* * *}$ \\
\hline Devam Bağl1lığ & & Dişsal Tatmin & 0,144 \\
\hline Normatif Bağlllık & $\longrightarrow$ & Dişsal Tatmin & $0,972^{* * *}$ \\
\hline$* * * p \leq 0,001 \quad{ }^{* *} \mathrm{p} \leq 0,01$ & ${ }^{*} \mathrm{p} \leq 0,05$
\end{tabular}

Duygusal bağlılığın, içsel tatmini üzerinde anlamlı bir etkisi yoktur $(\beta=0,042 ; p \geq 0,05)$. Bu sonuca göre H2a hipotezi (duygusal bağlılık, içsel tatmini pozitif yönlü etkilemektedir) reddedilmiştir. Devam bağlılığı, içsel tatmini $(\beta=0,994 ; p \leq 0,001)$ anlamlı ve pozitif bir şekilde etkilemektedir. Bu sonuca göre $\mathrm{H} 2 \mathrm{~b}$ hipotezi (devam bağlılı̆̆ı, içsel tatmini pozitif yönlü etkilemektedir) kabul edilmiştir. Normatif bağlılık, içsel tatmini $(\beta=-0,382 ; p \leq 0,01)$ anlamlı ve negatif bir şekilde etkilemektedir. Bu sonuca göre H2c hipotezi (normatif bağl1lık, içsel tatmini pozitif yönlü etkilemektedir) reddedilmiştir. Duygusal bağlılık, dişsal tatmini ( $\beta=-$ 0,552; $\mathrm{p} \leq 0,001)$ anlamlı ve negatif bir şekilde etkilemektedir. Bu sonuca göre H2d hipotezi (duygusal bağlılık, dışsal tatmini pozitif yönlü etkilemektedir) reddedilmiştir. Devam bağlılığı, dişsal tatmini üzerinde anlamlı bir etkisi yoktur $(\beta=0,144 ; \mathrm{p} \geq 0,05)$. Bu sonuca göre H2e hipotezi (devam bağlılığı, dişsal tatmini pozitif yönlü etkilemektedir) reddedilmiştir. Normatif bağlılık, dışsal tatmini $(\beta=0,972 ; p \leq 0,001)$ anlamlı ve pozitif bir şekilde etkilemektedir. Bu sonuca göre H2f hipotezi (normatif bağlılık, dışsal tatmini pozitif yönlü etkilemektedir) kabul edilmiştir. Bu sonuçlara göre $\mathrm{H} 2$ hipotezi (örgütsel bağlılık, iş tatminini pozitif yönlü etkilemektedir) kısmen kabul edilmiştir. Üçüncü model, iş tatmini ile işgören performansı arasındaki etkiyi gösteren bir yol modeli Şekil 8'deki gösterilmektedir.

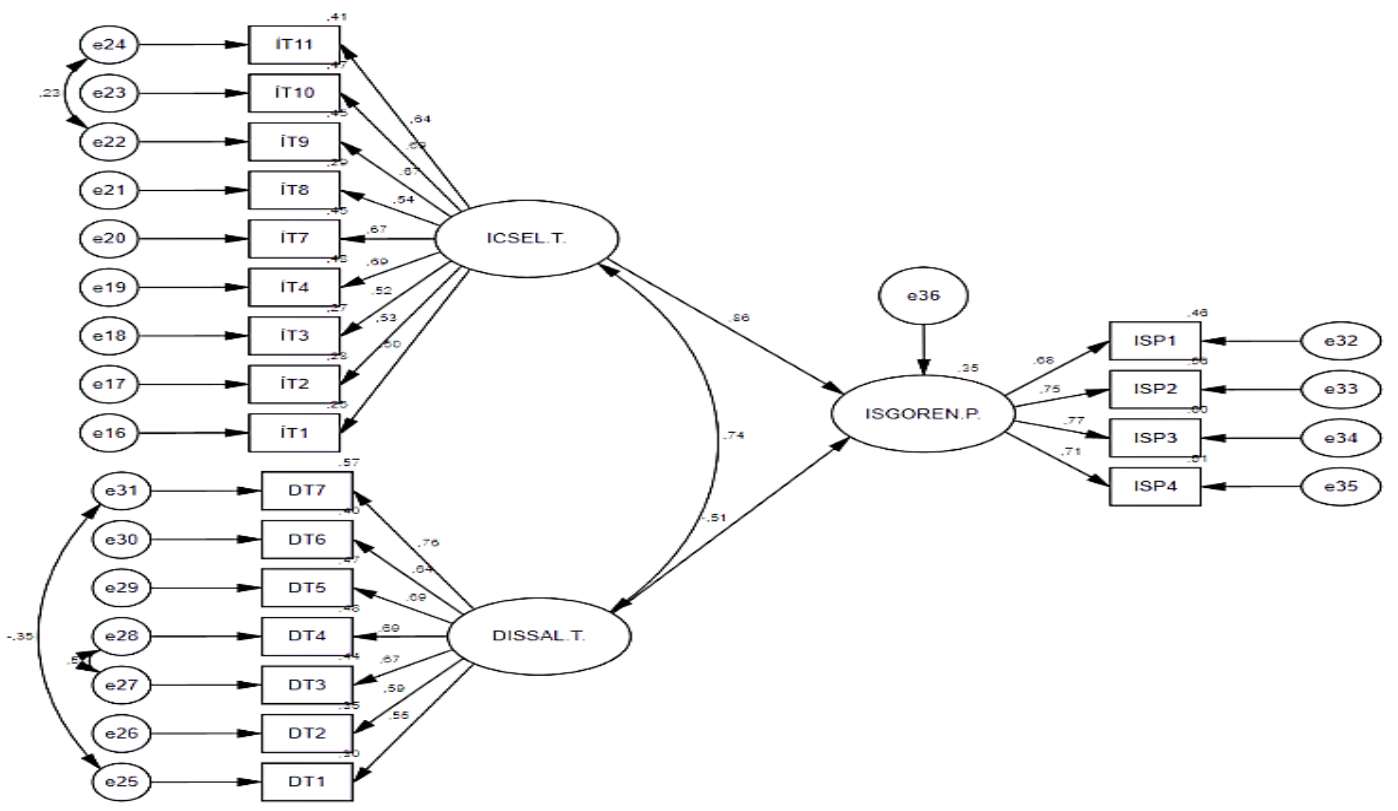

Şekil 8: Aracılık Rolü İçin Önerilen Modelin Yol Analizi (Aşama-I) 
İş tatmininin (aracı değişken), işgören performansını (bağımlı değişken) etkileme durumuyla ilgili yol analizi yapılmıştır. Yol analizi için önerilen modelin değeri $\left(X^{2}{ }_{164}=388,830\right.$; $\mathrm{X}^{2} / \mathrm{sd}=2,371 ; \mathrm{p} \leq 0,05 ; \mathrm{RMSEA}=0,070 ; \mathrm{CFI}=0,896$; $\mathrm{GFI}=0,880 ; \mathrm{AGFI}=0,846$ ) iyi uyum ve kabul edilebilir değerler içinde çıkmıştır. İş tatmininin işgören performansını etkileme durumu Tablo 13'te gösterilmektedir.

Tablo 13: İş Tatmininin İşgören Performansını Etkileme Durumu

\begin{tabular}{|c|c|l|c|}
\hline Aracı Değişken & Etki Yönü & Bağımlı Değişken & Standardize Regresyon Değeri $(\beta)$ \\
\hline İçsel Tatmin & $\longrightarrow$ & İşgören Performansı & $0,863^{* * * *}$ \\
\hline Dişsal Tatmin & $\longrightarrow$ & İşgören Performansı & $-0,505^{* * *}$ \\
\hline${ }_{* * * *} \mathrm{p} \leq 0,001$ & ${ }^{* *} \mathrm{p} \leq 0,05$ & \multicolumn{2}{c}{}
\end{tabular}

İçsel tatmin, işgören performansını $(\beta=0,863 ; p \leq 0,001)$ anlamlı ve pozitif bir şekilde etkilemektedir. $\mathrm{Bu}$ sonuca göre $\mathrm{H} 3 \mathrm{a}$ hipotezi (içsel tatmin, işgören performansını pozitif yönlü etkilemektedir) kabul edilmiştir. Dışsal tatmin, işgören performansını $(\beta=-0,505$; $\mathrm{p} \leq 0,001$ ) anlamlı ve negatif bir şekilde etkilemektedir. Bu sonuca göre H3b hipotezi (dışsal tatmin, işgören performansını pozitif yönlü etkilemektedir) reddedilmiştir. Bu sonuçlara göre H3 hipotezi (iş tatmini, işgören performansını pozitif yönlü etkilemektedir) kısmen kabul edilmiştir. Dördüncü model, örgütsel bağlılık ile işgören performansı arasındaki ilişkide iş tatmininin aracılık etkisini gösteren bir yol modeli Şekil 9'da gösterilmektedir.

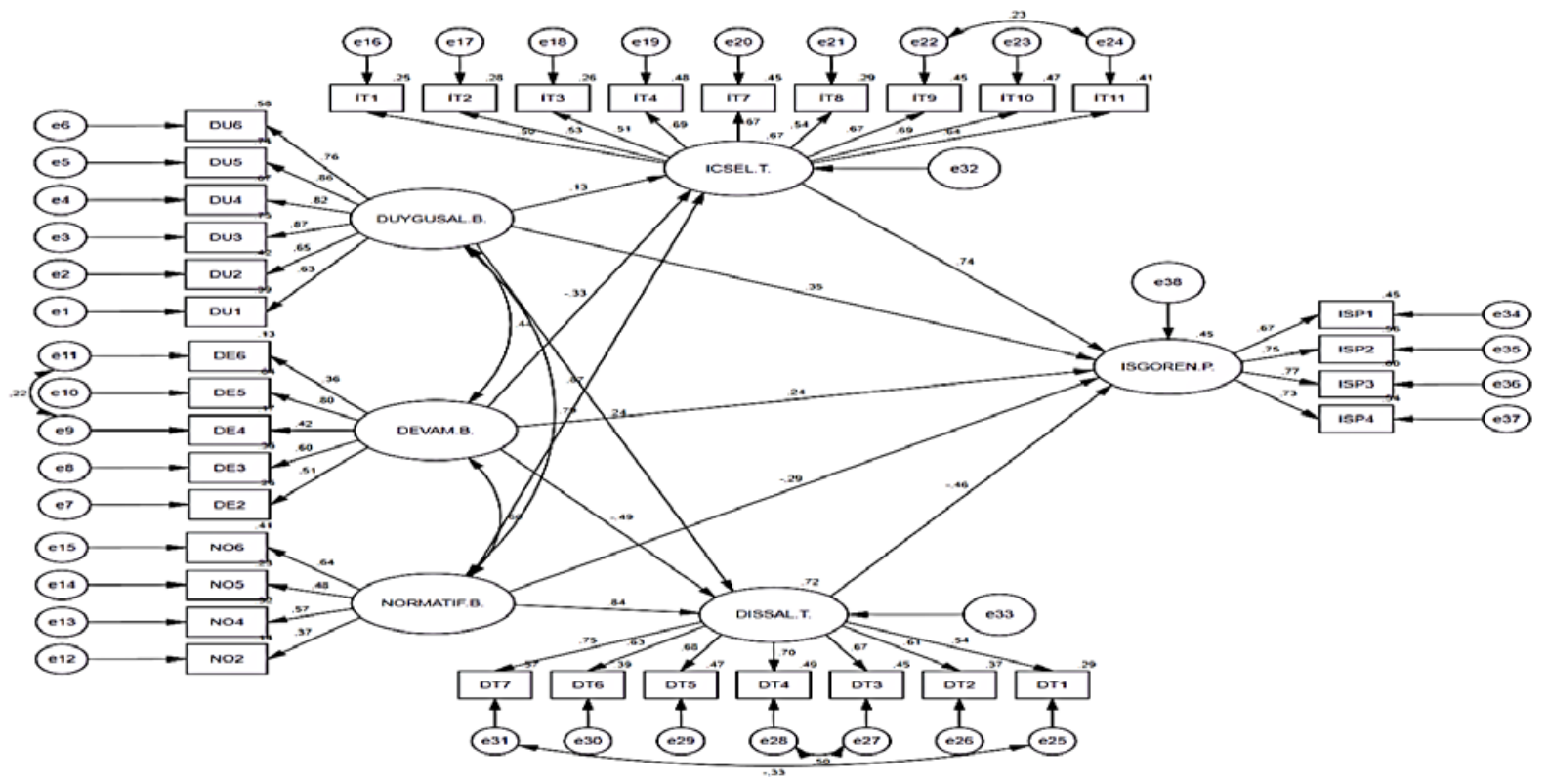

Şekil 9: Aracılık Rolü İçin Önerilen Modelin Yol Analizi (Aşama-II)

Örgütsel bağlılık (bağımsız değişken) ile işgören performansı (bağımlı değişken) arasındaki ilişkide iş tatmininin (aracı değişken) aracılık rolünün belirlenmesine yönelik yol analizi yapılmıştır. Yol analizi için önerilen modelin değeri $\left(X^{2}{ }_{542}=1074,018 ; X^{2} / s d=1,982 ; p \leq 0,05\right.$; RMSEA=0,059; CFI=0,870) iyi uyum ve kabul edilebilir değerler içinde çıkmıştır. Örgütsel bağl1lık, iş tatmini ve işgören performansı arasındaki etki durumu Tablo 14'te gösterilmiştir. 
Tablo 14: Örgütsel Bağlılık İle İşgören Performansı Arasındaki İlişkide İş Tatmininin Aracılık Etkisi

\begin{tabular}{|c|c|c|c|}
\hline Bağımsız Değişken & Etki Yönü & Bağımlı Değişken & Standardize Regresyon Değeri $(\beta)$ \\
\hline Duygusal Bağlılık & $\longrightarrow$ & İşgören Performansı & $0,351^{* *}$ \\
\hline Devam Bağlılı̆̆1 & & İşgören Performans1 & 0,245 \\
\hline Normatif Bağlılık & & İşgören Performansı & $-0,290$ \\
\hline Duygusal Bağlilık & & İçsel Tatmin & 0,131 \\
\hline Duygusal Bağlılık & & Dişsal Tatmin & 0,240 \\
\hline Devam Bağlılı̆̆1 & & İçsel Tatmin & $-0,330^{* *}$ \\
\hline Devam Bağlılı̆̆1 & & Dişsal Tatmin & $-0,493^{* * *}$ \\
\hline Normatif Bağlılık & $\rightarrow$ & İçsel Tatmin & $0,867^{* * *}$ \\
\hline Normatif Bağlilık & & Dişsal Tatmin & $0,838^{* * *}$ \\
\hline İçsel Tatmin & $\longrightarrow$ & İşgören Performansı & $0,743^{* * *}$ \\
\hline Dişsal Tatmin & $\longrightarrow$ & İşgören Performansı & $-0,458^{*}$ \\
\hline
\end{tabular}

Duygusal bağl1lık, işgören performansını $(\beta=0,351 ; p \leq 0,01)$ anlamlı ve pozitif bir şekilde etkilemektedir. Devam bağlılığının, işgören performansı üzerinde anlamlı bir etkisi yoktur $(\beta=0,245 ; p \geq 0,05)$. Normatif bağlllığın, işgören performansı üzerinde anlamlı bir etkisi yoktur $(\beta=-0,290 ; p \geq 0,05)$. Duygusal bağlılığın, içsel tatmin üzerinde anlamlı bir etkisi yoktur $(\beta=0,131 ; p \geq 0,05)$. Duygusal bağlılığın, dişsal tatmin üzerinde anlamlı bir etkisi yoktur $(\beta=0,240 ; p \geq 0,05)$. Devam bağlılığı, içsel tatmini $(\beta=-0,330 ; p \leq 0,01)$ anlamlı ve negatif bir şekilde etkilemektedir. Devam bağlılığı, dişsal tatmini $(\beta=-0,493 ; p \leq 0,001)$ anlamlı ve negatif bir şekilde etkilemektedir. Normatif bağlılık, içsel tatmini $(\beta=0,867 ; p \leq 0,001)$ anlamlı ve pozitif bir şekilde etkilemektedir. Normatif bağlılık, dışsal tatmini $(\beta=0,838 ; p \leq 0,001)$ anlamlı ve pozitif bir şekilde etkilemektedir. İçsel tatmin, işgören performansını $(\beta=0,743 ; p \leq 0,001)$ anlamlı ve pozitif bir şekilde etkilemektedir. Dışsal tatmin, işgören performansını $(\beta=-0,458$; $p \leq 0,05)$ anlamlı ve negatif bir şekilde etkilemektedir. Sonuç olarak; duygusal bağlılık ile işgören performansı arasındaki ilişkide içsel tatminin "aracılık rolü" yoktur. Duygusal bağlılık ile işgören performansı arasındaki ilişkide dışsal tatminin "tam aracılık rolü" vardır. Devam bağlılığı ile işgören performansı arasındaki ilişkide içsel tatminin "kısmi aracılık rolü" vardır. Devam bağlılığı ile işgören performansı arasındaki ilişkide dışsal tatminin "aracılık rolü" yoktur. Normatif bağlılık ile işgören performansı arasındaki ilişkide içsel tatminin "aracılık rolü" yoktur. Normatif bağlılık ile işgören performansı arasındaki ilişkide dişsal tatminin "aracılık rolü" yoktur. Bu sonuçlara göre H4 hipotezi (örgütsel bağlılık ile işgören performansı arasındaki ilişkide iş tatmininin aracılık rolü vardır) kısmen kabul edilmiştir. Baron ve Kenny'e (1986) göre çözümlenen bu modelde duygusal bağlılık ile işgören performansı arasındaki ilişkide dışsal tatminin "tam aracılık rolü" Şekil 10'da gösterilmektedir.

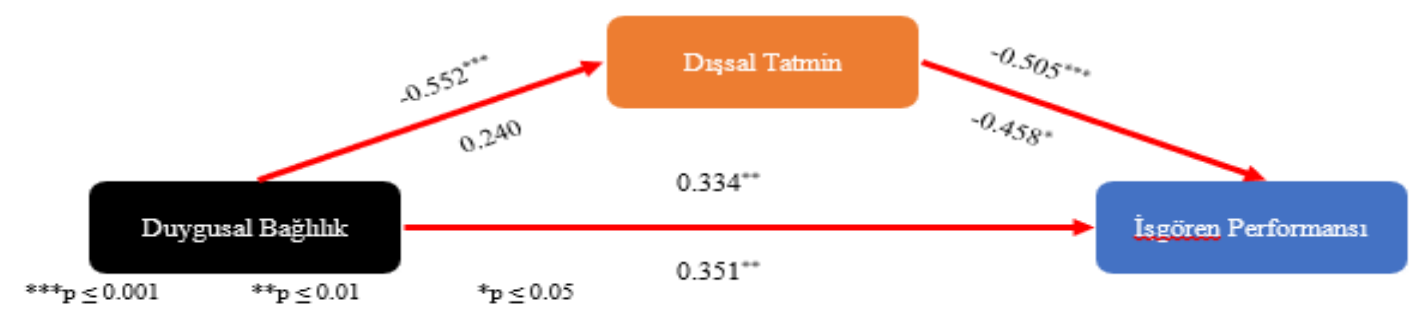

Şekil 10: Tam Aracılık Rolü 
Aracılık rolünün belirlenmesi için iki aşamalı 4 model kurulmuştur. Birinci aşamada 3 model test edilmiştir. Model 1'de duygusal bağlılığın işgören performansını anlamlı bir şekilde etkilemesi beklenmektedir $(\beta=0,334 ; p \leq 0,01)$. Model 2 'de duygusal bağl1lığın dişsal tatmini anlamlı bir şekilde etkilemesi beklenmektedir $(\beta=-0,552 ; p \leq 0,001)$. Model 3'te dişsal tatminin işgören performansını anlamlı bir şekilde etkilemesi beklenmektedir $(\beta=-0,505 ; p \leq 0,001)$. İkinci aşamada son model test edilmiştir. Bu son modelde üç sonuç yer alabilmektedir. Bunlar; (i) Tam Aracılık Rolü: Duygusal bağlılığın dışsal tatmini etkilememesi, (ii) Kısmi Aracılık Rolü: Duygusal bağlılığın dişsal tatmini ilk duruma göre daha düşük seviyede etkilemesi ve (iii) Aracılık Rolünün Bulunmaması: Duygusal bağlılı̆̆ın dışsal tatmini ilk duruma göre daha yüksek seviyede etkilemesi şeklindedir. Model 4 'te duygusal bağlılığın dişsal tatmini $(\beta=0,240 ; p \geq 0,05)$ etkilemediği görülmektedir. Bu sonuçlar tam aracılık rolünün olduğunu göstermektedir. Baron ve Kenny'e (1986) göre çözümlenen bu modelde devam bağlılığı ile işgören performansı arasındaki ilişkide içsel tatminin "kısmi aracılık rolü" Şekil 11 'de gösterilmektedir.

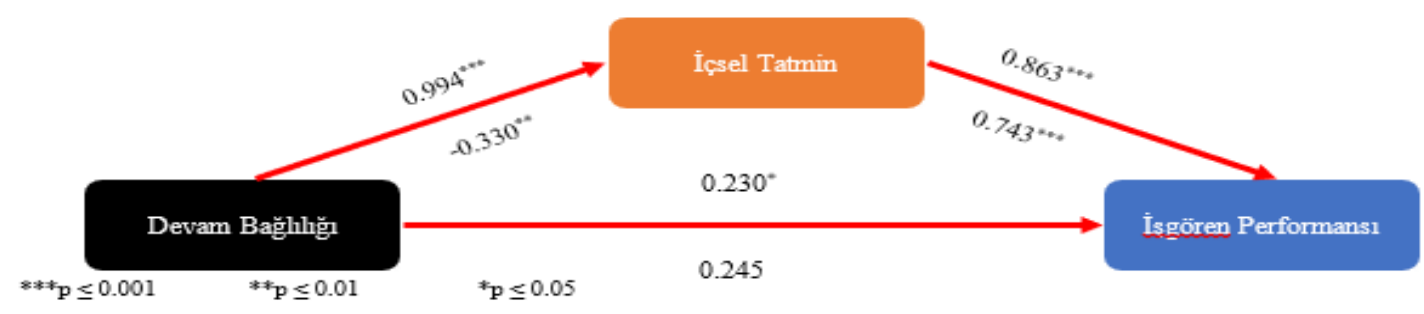

Şekil 11: Kısmi Aracilık Rolü

Aracılık rolünün belirlenmesi için iki aşamalı 4 model kurulmuştur. Birinci aşamada 3 model test edilmiştir. Model 1'de devam bağlılığının işgören performansını anlamlı bir şekilde etkilemesi beklenmektedir $(\beta=0,230 ; p \leq 0,05)$. Model 2 'de devam bağlilığının içsel tatmini anlamlı bir şekilde etkilemesi beklenmektedir $(\beta=0,994 ; p \leq 0,001)$. Model 3 'te içsel tatminin işgören performansını anlamlı bir şekilde etkilemesi beklenmektedir $(\beta=0,863 ; p \leq 0,001)$. İkinci aşamada son model test edilmiştir. Bu son modelde üç sonuç yer alabilmektedir. Bunlar; (i) Tam Aracılık Rolü: Devam bağlılığının içsel tatmini etkilememesi, (ii) Kısmi Aracılık Rolü: Devam bağlılığının içsel tatmini ilk duruma göre daha düşük seviyede etkilemesi ve (iii) Aracılık Rolünün Bulunmaması: Devam bağlılığının içsel tatmini ilk duruma göre daha yüksek seviyede etkilemesi şeklindedir. Model 4 'te devam bağlilığının içsel tatmini $(\beta=-0,330 ; \mathrm{p} \leq 0,01)$ daha düşük seviyede etkilediği görülmektedir. Bu sonuçlar, kısmi aracılık rolünün olduğunu göstermektedir. Araştırma için test edilen alternatif hipotezlerinin sonuçları Tablo 15'te gösterilmektedir. 
Tablo 15: Alternatif Hipotezlerin Derlenmiş Hali

\begin{tabular}{|c|c|c|}
\hline Kod & Alternatif Hipotez & Sonuç \\
\hline $\mathrm{H}_{1}$ & Örgütsel bağlılık, İşgören performansını pozitif yönlü etkilemektedir. & Kismen Kabul \\
\hline $\mathrm{H}_{1 \mathrm{a}}$ & Duygusal bağlılık, işgören performansını pozitif yönlü etkilemektedir. & Kabul \\
\hline $\mathrm{H}_{1 \mathrm{~b}}$ & Devam bağlılığı, işgören performansını pozitif yönlü etkilemektedir. & Kabul \\
\hline $\mathrm{H}_{1 \mathrm{c}}$ & Normatif bağlılık, işgören performansını pozitif yönlü etkilemektedir. & Ret \\
\hline $\mathrm{H}_{2}$ & Örgütsel bağlılık, iş tatminini pozitif yönlü etkilemektedir. & Kismen Kabul \\
\hline $\mathrm{H}_{2 \mathrm{a}}$ & Duygusal bağlılık, içsel tatmini pozitif yönlü etkilemektedir. & Ret \\
\hline $\mathrm{H}_{2 b}$ & Devam bağlılığı, içsel tatmini pozitif yönlü etkilemektedir. & Kabul \\
\hline $\mathrm{H}_{2 \mathrm{c}}$ & Normatif bağlılık, içsel tatmini pozitif yönlü etkilemektedir. & Ret \\
\hline $\mathrm{H}_{2 \mathrm{~d}}$ & Duygusal bağl1lık, dışsal tatmini pozitif yönlü etkilemektedir. & Ret \\
\hline $\mathrm{H}_{2 \mathrm{e}}$ & Devam bağlılı̆̆ı, dışsal tatmini pozitif yönlü etkilemektedir. & Ret \\
\hline $\mathrm{H}_{2 \mathrm{f}}$ & Normatif bağlılık, dışsal tatmini pozitif yönlü etkilemektedir. & Kabul \\
\hline $\mathrm{H}_{3}$ & İş tatmini, işgören performansını pozitif yönlü etkilemektedir. & Kismen Kabul \\
\hline $\mathrm{H}_{3 \mathrm{a}}$ & İçsel tatmin, işgören performansını pozitif yönlü etkilemektedir. & Kabul \\
\hline $\mathrm{H}_{3 b}$ & Dışsal tatmin, işgören performansını pozitif yönlü etkilemektedir. & Ret \\
\hline $\mathrm{H}_{4}$ & $\begin{array}{l}\text { Örgütsel bağlılık ile işgören performansı arasındaki ilişkide iş tatmininin aracılık rolü } \\
\text { vardır. }\end{array}$ & Kismen Kabul \\
\hline
\end{tabular}

\section{SONUÇ}

Bu çalışmada duygusal bağlılığın, işgören performansını olumlu olarak etkilediği sonucuna ulaşılmıştır. Üniversite bünyesinde çalışan idari personel eğer çalışmakta olduğu üniversitenin misyon, vizyon ve öz değerlerini benimser ve bu doğrultuda bir bağlılık oluşursa, işgörenlerin performans seviyelerinde olumlu bir değişim gerçekleştireceği öngörülmektedir. Altaş ve Çekmecelioğlu'nun (2007), Özkutlu'nun (2008), Çağırağası'nın (2013), Çekmecelioğlu'nun (2014), Doğanay ve Şen'in (2016), Ahmetoğulları ve Çatı'nın (2017), Aksoy vd.'nin (2018) ve Uludağ' in (2018) çalışmalarında elde edilmiş olan sonuç, bu çalışmada elde edilen sonucu desteklemektedir. İraz ve Akgün'ün (2011) ve Çekmecelioğlu ve Pelenk (2015) çalışmalarında elde edilmiş olan sonuç, bu çalışmada elde edilen sonucu desteklememektedir.

$\mathrm{Bu}$ çalışmada devam bağlılığının, işgören performansını olumlu olarak etkilediği sonucuna ulaşılmıştır. Üniversite bünyesinde çalışan idari personel eğer çalışmakta olduğu kurumun kendisine yapmış olduğu yatırımın yüksek seviyede olduğuna inanırsa bir bağlılık oluşmaktadır. Bu bağlılığın, işgörenlerin performans seviyelerinde olumlu bir değişim gerçekleştireceği öngörülmektedir. Özkutlu'nun (2008), İraz ve Akgün'ün (2011), Çağırağası'nın (2013), Çekmecelioğlu ve Pelenk'in (2015), Ahmetoğulları ve Çatı'nın (2017), Aksoy vd.'nin (2018) ve Uludağ'ın (2018) çalışmalarında elde edilmiş olan sonuç, bu çalışmada elde edilen sonucu desteklemektedir. Doğanay ve Şen'in (2016) çalışmasında elde edilmiş olan sonuç, bu çalışmada elde edilen sonucu desteklememektedir.

$\mathrm{Bu}$ çalışmada normatif bağlılı̆̆ın, işgören performansı üzerinde bir etkisinin olmadığı sonucuna ulaşılmıştır. Üniversite bünyesinde çalışan idari personelin çalışmakta olduğu üniversiteye duyduğu minnettarlık sonucu bir bağlılık oluşmaktadır. Bu bağlılığın, işgörenlerin performans seviyelerinde olumlu veya olumsuz bir etkisi bulunmamaktadır. Özkutlu'nun (2008), İraz ve Akgün'ün (2011) ve Çağırağası'nın (2013) çalışmalarında elde edilmiş olan sonuç, bu çalışmada elde edilen sonucu desteklemektedir. Altaş ve Çekmecelioğlu'nun (2007), Çekmecelioğlu ve Pelenk'in (2015), Doğanay ve Şen'in (2016), 
Ahmetoğulları ve Çatı'nın (2017), Aksoy vd.'nin (2018) ve Uludağ'ın (2018) çalışmalarında elde edilmiş olan sonuç, bu çalışmada elde edilen sonucu desteklememektedir.

Bu çalışmada duygusal bağlılığın, içsel tatmine bir etkisinin olmadığı sonucuna ulaşılmıştır. İşgörenler çalışmakta oldukları kurumlarda yeteneklerini kullanabilmesi, başarma hissinin oluşması, karar alma özgürlügünün verilmesi ve saygın bir statü elde etmesinin sağlanması gibi durumlar işgörenler de bir memnuniyet duygusu oluşturmaktadır. Bu memnuniyet duygusu içsel tatmin olarak adlandırılmaktadır. Üniversite bünyesinde çalışan idari personelin kurumuna karşı algılamış olduğu duygusal bağlılığın içsel tatmin üzerinde olumlu veya olumsuz bir etkisi bulunmamaktadır. Yalçınsoy ve Aksoy'un (2019) çalışmasında elde etmiş olduğu sonuç, bu çalışmada elde edilen sonucu desteklemektedir. Aşan ve Özyer'in (2008), Poyraz ve Kama'nın (2008), Malik vd.'nin (2010), Yıldırım vd.'nin (2011), Adekola'nın (2012), Yumuşak vd.'nin (2013), Çelik vd.'nin (2015), Fard ve Karimi'nin (2015), Hoş ve Oksay'ın (2015), Zeynel ve Çarıkçı'nın (2015), Dedeoğlu vd.'nin (2016), Sökmen ve Bıyık'ın (2016), Acar ve Türkoğlu'nun (2017), Aydın vd.'nin (2017), Özdemir vd.'nin (2017), Özmen ve Kahraman'ın (2017), Babadağ ve Arlı'nın (2018), Bekmezci ve Mert'in (2018), Büyükyılmaz vd.'nin (2018), Kırkpınar ve İşcan'ın (2018), Bora Kılınçarslan ve Küçüksüleymanoğlu'nun (2019), Özkan vd.'nin (2019), Yüksel ve Düşükcan'ın (2019), Güler ve Bircan'ın (2020) ve Kahyaoğlu ve Akca'nın (2020) çalışmalarında elde edilmiş olan sonuç, bu çalışmada elde edilen sonucu desteklememektedir.

Bu çalışmada devam bağlılığının, içsel tatmini olumlu olarak etkilediği sonucuna ulaşılmıştır. Üniversite bünyesinde çalışan idari personelin çalıştığı kuruma karşı hissetmiş olduğu devam bağlılığının içsel tatmin üzerinde olumlu veya olumsuz bir etkisi yoktur. Poyraz ve Kama'nın (2008), Malik vd.'nin (2010), Yıldırım vd.'nin (2011), Yumuşak vd.'nin (2013), Çelik vd.'nin (2015), Fard ve Karimi'nın (2015), Hoş ve Oksay'ın (2015), Zeynel ve Çarıkçı'nın (2015), Dedeoğlu vd.'nin (2016), Sökmen ve Bıyık'ın (2016), Acar ve Türkoğlu'nun (2017), Aydın vd.'nin (2017), Özdemir vd.'nin (2017), Özmen ve Kahraman'ın (2017), Babadağ ve Arlı'nın (2018), Bekmezci ve Mert'in (2018), Hatipoğlu ve Dündar'ın (2018), Kırkpınar ve İşcan'ın (2018), Bora Kılınçarslan ve Küçüksüleymanoğlu'nun (2019), Yüksel ve Düşükcan'ın (2019), Güler ve Bircan'ın (2020) ve Kahyaoğlu ve Akca'nın (2020) çalışmalarında elde edilmiş olan sonuç, bu çalışmada elde edilen sonucu desteklemektedir. Adekola'nın (2012), Özkan vd.'nin (2019) ve Yalçınsoy ve Aksoy'un (2019) çalışmalarında elde edilmiş olan sonuç, bu çalışmada elde edilen sonucu desteklememektedir.

$\mathrm{Bu}$ çalışmada normatif bağlılığın, içsel tatmini olumsuz yönde etkilediği sonucuna ulaşılmıştır. Üniversite bünyesinde çalışan idari personelin çalıştığı kuruma karşı duymuş olduğu minnettarlık duygusunun içsel tatmin üzerinde olumsuz bir etkisi vardır. Özkan vd.'nin (2019) çalışmasında elde etmiş olduğu sonuç, bu çalışmada elde edilen sonucu desteklemektedir. Altaş ve Çekmecelioğlu'nun (2007), Poyraz ve Kama'nın (2008), Malik vd.'nin (2010), Yıldırım vd.'nin (2011), Adekola'nın (2012), Yumuşak vd.'nin (2013), Çelik vd.'nin (2015), Fard ve Karimi'nin (2015), Hoş ve Oksay'ın (2015), Zeynel ve Çarıkçı'nın (2015), Dedeoğlu vd.'nin (2016), Sökmen ve Bıyık'ın (2016), Acar ve Türkoğlu'nun (2017), Aydın vd.'nin (2017), Özdemir vd.'nin (2017), Özmen ve Kahraman'ın (2017), Babadağ ve Arlı'nın (2018), Bekmezci ve Mert'in (2018), Kırkpınar ve İşcan'ın (2018), Yalçınsoy ve Aksoy'un (2019), Yüksel ve Düşükcan'ın (2019), Güler ve Bircan'ın (2020) ve Kahyaoğlu ve 
Akca'nın (2020) çalışmalarında elde edilmiş olan sonuç, bu çalışmada elde edilen sonucu desteklememektedir.

$\mathrm{Bu}$ çalışmada duygusal bağlılığın, dişsal tatmini olumsuz yönde etkilediği sonucuna ulaşılmıştır. İşgörenlerin çalışmakta oldukları kurumlardaki almış oldukları ücretler, terfi imkanı, çalışma koşulları ve takdir edilmesi gibi etmenlerden dolayı memnun olma durumu dışsal tatmini oluşturmaktadır. İşgörenlerin çalışmakta oldukları üniversitenin hedeflerini benimsemesi sonucu oluşan bağl1lık durumunun, işgörenlerin dişsal tatmin düzeyi üzerinde olumsuz bir değişim gerçekleştireceği öngörülmektedir. Özkan vd.'nin (2019) çalışmasında elde etmiş olduğu sonuç, bu çalışmada elde edilen sonucu desteklemektedir. Aşan ve Özyer'in (2008), Poyraz ve Kama'nın (2008), Malik vd.'nin (2010), Yıldırım vd.'nin (2011), Adekola'nın (2012), Yumuşak vd.'nin (2013), Çelik vd.'nin (2015), Hoş ve Oksay'ın (2015), Zeynel ve Çarıkçı'nın (2015), Dedeoğlu vd.'nin (2016), Sökmen ve Biyık'ın (2016), Acar ve Türkoğlu'nun (2017), Aydın vd.'nin (2017), Özdemir vd.'nin (2017), Özmen ve Kahraman'ın (2017), Babadağ ve Arlı'nın (2018), Bekmezci ve Mert'in (2018), Büyükyılmaz vd.'nin (2018), Kırkpınar ve İşcan'ın (2018), Bora Kılınçarslan ve Küçüksüleymanoğlu'nun (2019), Yalçınsoy ve Aksoy'un (2019), Yüksel ve Düşükcan'ın (2019), Güler ve Bircan'ın (2020) ve Kahyaoğlu ve Akca'nın (2020) çalışmalarında elde edilmiş olan sonuç, bu çalışmada elde edilen sonucu desteklememektedir.

$\mathrm{Bu}$ çalışmada devam bağlılığın, dışsal tatmin üzerinde bir etkisinin olmadığı sonucuna ulaşılmıştır. İşgörenlerin çalışmakta oldukları kurumun kendileri üzerinde yapmış oldukları katkılardan dolayı sahip oldukları bağlılık durumunun, işgörenlerin dişsal tatmin düzeyi üzerinde olumlu veya olumsuz bir etkisi bulunmamaktadır. Adekola'nın (2012) ve Yalçınsoy ve Aksoy'un (2019) çalışmalarında elde edilmiş olan sonuç, bu çalışmada elde edilen sonucu desteklemektedir. Poyraz ve Kama'nın (2008), Malik vd.'nin (2010), Yıldırım vd.'nin (2011), Yumuşak vd.'nin (2013), Çelik vd.'nin (2015), Hoş ve Oksay'ın (2015), Zeynel ve Çarıkçı'nın (2015), Dedeoğlu vd.'nin (2016), Sökmen ve Biyık'ın (2016), Acar ve Türkoğlu'nun (2017), Aydın vd.'nin (2017), Özdemir vd.'nin (2017), Özmen ve Kahraman'ın (2017), Babadağ ve Arlı'nın (2018), Bekmezci ve Mert'in (2018), Hatipoğlu ve Dündar'ın (2018), Kırkpınar ve İşcan'ın (2018), Bora Kılınçarslan ve Küçüksüleymanoğlu'nun (2019), Özkan vd.'nin (2019), Yüksel ve Düşükcan'ın (2019), Güler ve Bircan'ın (2020) ve Kahyaoğlu ve Akca'nın (2020) çalışmalarında elde edilmiş olan sonuç, bu çalışmada elde edilen sonucu desteklememektedir.

$\mathrm{Bu}$ çalışmada normatif bağlılığın, dışsal tatmini olumlu olarak etkilediği sonucuna ulaşılmıştır. İşgörenlerin çalışmakta oldukları kuruma karşı duymuş oldukları minnettarlık duygusu sonucu oluşan bağlllık durumunun, işgörenlerin dışsal tatmin düzeyi üzerinde olumlu bir değişim gerçekleştireceği öngörülmektedir. Poyraz ve Kama'nın (2008), Malik vd.'nin (2010), Yıldırım vd.'nin (2011), Adekola'nın (2012), Yumuşak vd.'nin (2013), Çelik vd.'nin (2015), Hoş ve Oksay'ın (2015), Zeynel ve Çarıkçı'nın (2015), Dedeoğlu vd.'nin (2016), Sökmen ve Bıyık'ın (2016), Acar ve Türkoğlu'nun (2017), Aydın vd.'nin (2017), Özdemir vd.'nin (2017), Özmen ve Kahraman'ın (2017), Babadağ ve Arlı'nın (2018), Bekmezci ve Mert'in (2018), Kırkpınar ve İşcan'ın (2018), Bora Kılınçarslan ve Küçüksüleymanoğlu'nun (2019), Yüksel ve Düşükcan'ın (2019), Güler ve Bircan'ın (2020) ve Kahyaoğlu ve Akca'nın (2020) çalışmalarında elde edilmiş olan sonuç, bu çalışmada elde edilen sonucu desteklemektedir. Özkan vd.'nin (2019) ve Yalçınsoy ve Aksoy'un (2019) çalışmalarında elde edilmiş olan sonuç, bu çalışmada elde edilen sonucu desteklememektedir. 
$\mathrm{Bu}$ çalışmada içsel tatminin, işgören performansını olumlu olarak etkilediği sonucuna ulaşılmıştır. Üniversitede çalışan işgörenlerin çalışma ortamındaki duygu ve düşüncelerinin önemsenmesi sonucu oluşan memnuniyet durumu (içsel tatmin), işgörenlerin performans düzeyleri üzerinde olumlu bir değişim gerçekleştireceği öngörülmektedir. Smeenk vd.'nin (2009), Kahya'nın (2013), Nergiz ve Yılmaz'ın (2016), Şahin ve Çankır'ın (2018), Çakıl ve Güney'in (2019) ve Marliati vd.'nin (2020) çalışmalarında elde edilmiş olan sonuç, bu çalışmada elde edilen sonucu desteklemektedir.

$\mathrm{Bu}$ çalışmada dışsal tatminin, işgören performansını olumsuz yönde etkilediği sonucuna ulaşılmıştır. Üniversitede çalışan işgörenlerin ücret, terfi ve çalışma koşulları gibi durumlardan dolayı oluşan memnuniyet durumu (dışsal tatmin), işgörenlerin performans düzeyleri üzerinde olumsuz bir değişim gerçekleştireceği öngörülmektedir. Smeenk vd.'nin (2008) çalışmasında elde etmiş olduğu sonuç, bu çalışmada elde edilen sonucu desteklemektedir. Kahya'nın (2013), Nergiz ve Yılmaz'ın (2016), Şahin ve Çankır'ın (2018), Çakıl ve Güney'in (2019) ve Marliati vd.'nin (2020) çalışmalarında elde edilmiş olan sonuç, bu çalışmada elde edilen sonucu desteklememektedir. Bu çalışmada elde edilen diğer sonuçlar; duygusal bağlılık ile işgören performansı arasındaki ilişkide dışsal tatminin "tam aracılık rolüne" sahip olması ve devam bağlılığı ile işgören performansı arasındaki ilişkide içsel tatminin "kısmi aracılık rolüne" sahip olması şeklindedir.

Üniversite çalışanlarının örgütsel bağlılık, işgören performansı ve iş tatmini düzeylerine bakıldığında çalışanların işgören performans düzeylerinin çok yüksek ve örgütsel bağlılık ile iş tatmini düzeylerinin ise yüksek olduğu tespit edilmiştir. Ayrıca örgütsel bağlılık, işgören performansı ve iş tatmininin birbirleri arasında pozitif yönlü bir ilişkinin olduğu belirlenmiştir. Duygusal bağlılık, işgören performansını pozitif olarak etkilerken dışsal tatmini negatif yönlü etkilemektedir. İçsel tatminin üzerinde ise bir etkisi bulunmamaktadır. Devam bağlılığı, işgören performansını ve içsel tatmini pozitif olarak etkilemektedir. Dışsal tatmin üzerinde ise bir etkisi yoktur. Normatif bağlılığın işgören performansı üzerinde bir etkisi olmamasına karşın içsel tatmini negatif olarak etkilemektedir. Dışsal tatmin üzerinde ise pozitif olarak bir etkisi vardır. İçsel tatmin, işgören performansını pozitif olarak etkilerken dışsal tatminin, işgören performansı üzerinde negatif yönlü bir etkisi bulunmaktadır.

$\mathrm{Bu}$ çalışmada elde edilen sonuçlar temelinde bundan sonraki araştırmacılara ve araştırmalara yön vermesi açısından; örgütsel bağlılık ile iş tatmini arasındaki ilişkide işgören performansının aracılık etkisinin veya iş tatmini ile işgören performansı arasındaki ilişkide örgütsel bağlılığın aracılık etkisinin incelenebileceği önerilmektedir. Araştırmada incelenen modelde değişkenlerin aracı rolü yerine düzenleyici rolünün belirlendiği çalışmalar yapılabileceği ve bu çalışmalarda elde edilen bulguların literatüre katkı sağlayacağı düşünülmektedir. Bu araştırmada elde edilen bulgular ışı̆̆ında yöneticilerin idari personelin mevcut durumdaki örgütsel bağlılık, işgören performansı ve iş tatmini düzeylerinin belirlenmesi ve bu belirlenen bulgular ışığında stratejiler oluşturması gerekmektedir. Bu oluşturulan stratejilerin mevcut durumu daha iyi kavrama ve daha iyi bir duruma getirilmesinde kılavuz olabileceği öngörülmektedir.

\section{KAYNAKÇA}

Acar, O. K. ve Türkoğlu, T. (2017). “Kamuda İşletmecilik Eksenli Değişimle Birlikte Çalışanlarda Örgütsel Bağlılık ve İş Tatmini Düzeyleri: PTT Üzerine Bir Alan 
Araştırması", Karamanoğlu Mehmetbey Üniversitesi Sosyal ve Ekonomik Araştırmalar Dergisi, 19(33), 93-102.

Adekola, B. (2012). “The Impact of Organizational Commitment on Job Satisfaction: A Study of Employees at Nigerian Universities", International Journal of Human Resource Studies, 2(2), 1-17.

Ağırkaya, K. ve Erdem, R. (2018). “Halef Selef Bağlamında Yönetici Değişikliğinin Hastane Personeline Etkisi", Süleyman Demirel Üniversitesi Sosyal Bilimler Enstitüsü Dergisi, (31), 23-60.

Ahmetoğulları, K. ve Çatı, K. (2017). “STK Mensuplarının Etik İklim Algısının Örgütsel Bağlılık Aracılığıyla Bireysel Performanslarına Etkisi", Mehmet Akif Ersoy Üniversitesi Sosyal Bilimler Enstitüsü Dergisi, 9(20), 283-313.

Aksoy, C., Şengün, H. İ. ve Yılmaz, Y. (2018). “Examination of The Relationship Between Job Satisfaction Levels and Organizational Commitments of Tourism Sector Employees: A Research in The Southeastern Anatolia Region of Turkey", Elektronik Sosyal Bilimler Dergisi, 17(65), 356-365.

Allen, N. J. \& Meyer, J. P. (1990). "The Measurement and Antecedents of Affective, Continuance and Normative Commitment to The Organization", Journal of Occupational Psychology, 63(1), 1-18.

Allen, N. J. \& Meyer, J. P. (1996). "Affective, Continuance, and Normative Commitment to the Organization: An Examination of Construct Validity", Journal of Vocational Behavior, 49(3), 252-276.

Altaş, S. S. ve Çekmecelioğlu, H. G. (2007). “İş Tatmini, Örgütsel Bağl1lık ve Örgütsel Vatandaşlık Davranışının İş Performansı Üzerindeki Etkileri: Bir Araştırma", Öneri, 7(28), 47-57.

Altun, E. (2019). “Çalışma Hayatında Örgütsel Bağlılık ve Performans Arasındaki İlişkinin İncelenmesi", Sağlık ve Sosyal Refah Araştırmaları Dergisi, 1(2), 1-13.

Arsezen, P. (2017). “Turizmde İşkoliklik Davranışı, İş Tatmini İle İşletme Performansı Arasındaki İlişkinin Analizi ve Örgüte Duygusal Bağlılığın Aracı Rolü: Antalya'da Bulunan Beş Yıldızlı Konaklama İşletmelerindeki Yöneticiler Örneği”, Kırklareli Üniversitesi İktisadi ve İdari Bilimler Fakültesi Dergisi, 6(5), 211-227.

Aşan, Ö. ve Özyer, K. (2008). “Duygusal Bağlılık İle İş Tatmini ve İş Tatmininin Alt Boyutları Arasındaki İlişkileri Analiz Etmeye Yönelik Ampirik Bir Çalışma”, Süleyman Demirel Üniversitesi İktisadi ve İdari Bilimler Fakültesi Dergisi, 13(3), 129-151.

Atılgan, Ö. (2017). “İş Tatmini İle İşgören Performansı İlişkisi: Öğretim Üyeleri Üzerinde Bir Araştırma”, Kafkas Üniversitesi İktisadi ve İdari Bilimler Fakültesi Dergisi, 8(15), 35-55.

Aydemir, M. ve Erşan, C. (2011). "Yeni Kurulan Üniversitelerde Örgütsel Bağlılık Sorunu", Afyon Kocatepe Üniversitesi İktisadi ve İdari Bilimler Fakültesi Dergisi, 3(1), 55-72.

Aydın, A. S., Akyüz, K. C., Yıldırım, İ. ve Köse, Ş. (2017). “İlk ve Orta Okullarda Görev Yapan Öğretmenlerin İş Tatmini ve Örgütsel Bağlllık Düzeylerinin Analizi", Uluslararası İktisadi ve İdari İncelemeler Dergisi, (18), 23-52. 
Aziri, B. (2011). "Job Satisfaction: A Literature Review", Management Research and Practice, $3(4), 77-86$.

Aziz, A. (2014). Sosyal Bilimlerde Araştırma Yöntemleri ve Teknikleri. 9. Baskı, Ankara: Nobel Yayıncilık.

Babadağ, M. ve Arlı, O. E. (2018). “Duygusal Tükenme İle Örgütsel Bağlılık Arasındaki İlişkide İş Tatmininin Aracı Rolü", Uluslararası İktisadi ve İdari İncelemeler Dergisi, (17. UİK Özel Say1s1), 167-182.

Babin, B. J. \& Boles, J. S. (1998). “Employee Behavior in a Service Environment: A Model and Test of Potential Differences Between Men and Women", Journal of Marketing, 62(2), 77-91.

Bağc1, Z. ve Demir, G. (2017). “Örgütlerde Adalet Algısının İş Tatmini Üzerine Etkisi: Akdeniz Üniversitesi İdari Personeli Üzerinde Bir Araştırma”, MANAS Sosyal Araştırmalar Dergisi, 6(4), 343-357.

Bakanauskiene, I., Bendaraviciene, R. \& Krikstolaitis, R. (2010). “Empirical Evidence on Employees' Communication Satisfaction and Job Satisfaction: Lithuania's University Case", Organizaciju Vadyba: Sisteminiai Tyrimai, (54), 21-36.

Baron, R. M. \& Kenny, D. A. (1986). “The Moderator-Mediator Variable Distinction in Social Psychological Research: Conceptual, Strategic, and Statistical Considerations", Journal of Personality and Social Psychology, 51(6), 1173-1182.

Barzoki, A. S. \& Sarand, V. F. (2015). “Investigating the Relationship between Organizational Justice, Organizational Commitment and Staff's Quality of Work Life (Case Study: Islamic Azad University employees Shabestar)", International Journal of Academic Research in Economics and Management Sciences, 4(2), 34-44.

Baycan, A. F. (1985). An Analysis of the Several Aspects of Job Satisfaction Between Different Occupational Groups. Boğaziçi Üniversitesi, Sosyal Bilimler Enstitüsü, Yayınlanmamış Yüksek Lisans Tezi, İstanbul.

Bayrak Kök, S. (2006). “İş Tatmini ve Örgütsel Bağlılığın İncelenmesine Yönelik Bir Araştırma", Atatürk Üniversitesi İktisadi ve İdari Bilimler Dergisi, 20(1), 291-317.

Baysal, A. C. ve Paksoy, M. (1999). “Mesleğe ve Örgüte Bağll1ı̆̆ı Çok Yönlü İncelenmesinde Meyer-Allan Modeli”, İstanbul Üniversitesi İşletme Fakültesi Dergisi, 28(1), 7-15.

Beğenirbaş, M. ve Can Yalçın, R. (2020). “Hizmet Çalışanlarının İş Tatmini ve Performansı Liderlik Algılamalarından Etkilenir Mi? Hizmetkâr Liderlik Örneği”, Kara Harp Okulu Bilim Dergisi, 30(1), 25-49.

Bekmezci, M. ve Mert, İ. S. (2018). “Çalışanların Görev Yaptığ1 Örgüt Kademesinin İş Tatmini ve Örgütsel Bağlılık Düzeyleri Üzerindeki Etkisi", Uluslararası İktisadi ve İdari Incelemeler Dergisi, (17. UİK Özel Sayısı), 747-760.

Bendaraviciene, R. \& Bakanauskiene, I. (2012). “Determinants of Different Groups Employees' Job Satisfaction: Lithuania's University Case", Human Resources Management and Ergonomics, 6(1), 6-17. 
Bıyık, Y., Şimşek, T. ve Erden, P. (2017). "Etik Liderliğin Çalışanların İş Performansı ve İş Tatminine Etkisi”, Gazi İktisat ve İşletme Dergisi, 3(1), 59-70.

Bora Kılınçarslan, T. ve Küçüksüleymanoğlu, R. (2019). “Muhasebe Meslek Mensuplarının Örgütsel Bağlılıklarının İş Tatmini Üzerindeki Etkisi”, Muhasebe Bilim Dünyası Dergisi, 21(4), 1078-1090.

Bos, J. T., Donders, N. C. G. M., “Bouwman-Brouwer, K. M. \& Van der Gulden, J. W. J. (2009). Work Characteristics and Determinants of Job Satisfaction in Four Age Groups: University Employees' Point of View", International Archives of Occupational and Environmental Health, 82(10), 1249-1259.

Bozdoğan, S. C. \& Aksoy, A. (2020). “Effect of Transformational Leadership on Job Performance and Job Satisfaction", Osmaniye Korkut Ata Üniversitesi İktisadi ve İdari Bilimler Fakültesi Dergisi, 4(1), 56-67.

Bozer, A. ve Yanık, A. (2020). “Üniversite Çalışanlarının Örgütsel Vatandaşlık Davranışı, İş Tatmini ve İş Performansı Arasındaki İlişki", Kırklareli Üniversitesi İktisadi ve İdari Bilimler Fakültesi Dergisi, 9(1), 125-143.

Brown, D. \& Sargeant, M. A. (2007). “Job Satisfaction, Organizational Commitment, and Religious Commitment of Full-Time University Employees", Journal of Research on Christian Education, 16(2), 211-241.

Busch, P. \& Bush, R. F. (1978). “Women Contrasted to Men in the Industrial Salesforce: Job Satisfaction, Values, Role Clarity, Performance and Propensity to Leave", Journal of Marketing Research, 15(3), 438-448.

Büyüköztürk, Ş. (2019). Sosyal Bilimler İçin Veri Analizi El Kitabı. 25. Baskı, Ankara: Pegem Yayıncilik.

Büyükyılmaz, O., Karakule, İ. ve Karataş, İ. (2018). “Örgütsel Kariyer Yönetiminin Duygusal Bağlılık Üzerindeki Etkisinde İş Tatmininin Aracılık Rolü”, Çankırı Karatekin Üniversitesi İktisadi ve İdari Bilimler Fakültesi Dergisi, 8(1), 1-29.

Byrne, B. M. (2016). Structural Equation Modeling with Amos: Basic Concepts, Applications and Programming. Third Edition, New York: Routledge-Taylor \& Francis Group.

Candan, H., Canbolat, M. A. ve Öksüz, Y. S. (2015). "Personel Güçlendirmenin Örgütsel Bağlılık Üzerine Etkisi: Bir Kamu Kurumunda Araştırma", Kahramanmaraş Sütçü İmam Üniversitesi İktisadi ve İdari Bilimler Fakültesi Dergisi, 5(2), 255-266.

Chen, C.-H., Yuan, M.-L., Cheng, J.-W. \& Seifert, R. (2016). “Linking Transformational Leadership and Core Self-Evaluation to Job Performance: The Mediating Role of Felt Accountability", The North American Journal of Economics and Finance, 35, 234-246.

Cindiloğlu Demirer, M. (2019). “Kişi Örgüt Uyumunun İş Performansı Üzerine Etkisi: Mutluluğun Aracılık Rolü", Atatürk Üniversitesi İktisadi ve İdari Bilimler Dergisi, 33(1), 283-302.

Clark, A. E. (1996). "Job Satisfaction in Britain", British Journal of Industrial Relations, 34(2), 189-217. 
Çağırağası, F. (2013). “Özel Güvenlik Sektöründe Çalışanların Örgütsel Bağlılık, İş Motivasyonu, İş Performans Düzeyleri ve Bir Uygulama", Elektronik Mesleki Gelişim ve Araştırmalar Dergisi, 1(1), 34-53.

Çakıl, R. ve Güney, S. (2019). “İşletmelerde Performans Değerlendirmenin Çalışanların İş Tatminine Etkisi ve Bir Uygulama”, Anadolu Bil Meslek Yüksekokulu Dergisi, 14(53), 4560 .

Çekmecelioğlu, H. G. (2014). “Göreve ve İnsana Yönelik Liderlik Tarzlarının Örgütsel Bağlılık, İş Performansı ve İşten Ayrılma Niyeti Üzerindeki Etkileri”, Kocaeli Üniversitesi Sosyal Bilimler Dergisi, (28), 21-34.

Çekmecelioğlu, H. G. ve Pelenk, S. E. (2015). “Örgütsel Engellerin, Örgütsel Bağlllık ve İş Performansı Üzerindeki Etkileri: Kocaeli Lastik İşletmelerinde Bir Araştırma”, Kocaeli Üniversitesi Sosyal Bilimler Dergisi, (29), 143-164.

Çelik, S., Dedeoğlu, B. B. ve İnanır, A. (2015). “Relationship Between Ethical Leadership, Organizational Commitment and Job Satisfaction at Hotel Organizations", Ege Akademik Bakış, 15(1), 53-63.

Çevik, H. ve Şimşek, K. Y. (2017). “Organizational Commitment of Individuals Participating in Intramural Sports: A Study on University Employees", Niğde Üniversitesi Beden Eğitimi ve Spor Bilimleri Dergisi, 11(3), 268-277.

Çınar, O. ve Gündoğdu, M. (2019). “İş Sağlığı-Güvenliği, İş Tatmini ve Örgütsel Bağlılık Arasındaki İlişkinin İncelenmesi: Erzurum ve İstanbul Uygulaması", İş ve Hayat, 5(9), 231-247.

Çöl, G. (2008). “Algılanan Güçlendirmenin İşgören Performansı Üzerine Etkileri”, Doğuş Üniversitesi Dergisi, 9(1), 35-46.

Çöl, G. ve Gül, H. (2005). “Kişisel Özelliklerin Örgütsel Bağlılık Üzerine Etkileri ve Kamu Üniversitelerinde Bir Uygulama”, Atatürk Üniversitesi İktisadi ve İdari Bilimler Dergisi, 19(1), 291-306.

Çöp, S. ve Doğanay, A. (2020). "Algılanan Liderlik İletişiminin İş Performansı ve İş Tatminine Etkisi: 4 ve 5 Yıldızlı Otel Çalışanları Üzerine Bir Araştırma", İstanbul Gelişim Üniversitesi Sosyal Bilimler Dergisi, 7(1), 34-49.

Davidson, R. A. (2001). Behavioral Research in Auditing: A Review and Synthesis. in Robert T Golembiewski (Ed.), Handbook of Organizational Behavior (p. 547-598). Second Edition, New York: Marcel Dekker Inc.

Dedeoğlu, B. B., Çelik, S., İnanır, A. ve Altay, H. (2016). “Etik Liderlik, Örgütsel Bağlılık ve İş Tatmini Arasındaki İlişkide: Cinsiyet ve Çalışma Süresinin Farklılaştırıcı (Moderate) Rolü", Yönetim ve Ekonomi Araştırmaları Dergisi, 14(4), 45-70.

Demir, N. (2006). “Satış Takımlarında İş Tatmini ve Örgütsel Bağl1lık”, Öneri, 7(26), 153-162.

Demir, N. (2009). “Tükenmişlik Sendromunun Örgütsel Bağlılık ve İş Tatmini Üzerindeki Etkisi", Öneri, 8(32), 193-202. 
Doğanay, A. ve Şen, E. (2016). Liderlik Tarzlarının Çalışanların Bağlılık Seviyesi ve Performansına Etkisi: Başakşehir Belediyesinde Bir Uygulama. Yalova Sosyal Bilimler Dergisi, 7(2), 324-348.

Düzgün, M. S. ve Marşap, A. (2018). Performans Değerlendirme ve Ücret Uygulamalarına İlişkin Algının İş Tatmini ve Örgütsel Bağllı̆̆a Etkisi: Bir Uygulama. Yönetim ve Ekonomi, 25(3), 787-810.

Ekşi, F., Dilmaç, B., Yaman, E. \& Hamarta, E. (2015). The Predictive Relationships between the Values of University Employees, Mobbing, and Organizational Commitment. Turkish Journal of Business Ethics, 8(2), 311-322.

Eşitti, B. ve Buluk, B. (2018). İçsel Pazarlama Faaliyetlerinin İş Performansına Etkisinde İş Tatmininin Aracı Rolü: Beş Yıldızlı Konaklama İşletmeleri Örneği. Akademik Araştırmalar ve Çalışmalar Dergisi, 10(18), 288-303.

Faramarzi, N. \& Khodaverdizadeh, N. (2013). "Analysis of the Influential Factors in Organizational Commitment (Case Study: Islamic Azad University Staff- Mashhad Branch)", European Online Journal of Natural and Social Sciences, 2(3), 1610-1615.

Fard, P. G. \& Karimi, F. (2015). “The Relationship between Organizational Trust and Organizational Silence with Job Satisfaction and Organizational Commitment of the Employees of University", International Education Studies, 8(11), 219-227.

Field, A. (2005). Discovering Statistics Using SPSS. Second Edition, London: Sage Publications.

George, D. \& Mallery, P. (2019). IBM SPSS Statistics 25 Step by Step: A Simple Guide and Reference. Fifteenth Edition, New York: Routledge Press.

Gruneberg, M. M. (1979). Understanding Job Satisfaction. London and Basingstoke: The Macmillan Press Ltd.

Gül, H. (2002). “Örgütsel Bağlılık Yaklaşımlarının Mukayesesi ve Değerlendirmesi”, Ege Akademik Bakış Dergisi, 2(1), 37-56.

Güler, A. ve Bircan, H. (2019). “İdari Personelin İş Tatmini ve Örgüte Bağlılığına Etki Eden Faktörlerin Belirlenmesi: Sivas Cumhuriyet Üniversitesi Örneği”, Kırşehir Ahi Evran Üniversitesi İktisadi ve İdari Bilimler Fakültesi Dergisi, 4(1), 10-33.

Güneş, İ., Bayraktaroğlu, S. ve Özen Kutanis, R. (2009). “Çalışanların Örgütsel Bağlılık ve Tükenmişlik Düzeyleri Arasındaki İlişki: Bir Devlet Üniversitesi Örneği”, Süleyman Demirel Üniversitesi İktisadi ve İdari Bilimler Fakültesi Dergisi, 14(3), 481-497.

Gürbüz, S. ve Şahin, F. (2018). Sosyal Bilimlerde Araştırma Yöntemleri: Felsefe-Yöntem-Analiz. Beşinci Baskı, Ankara: Seçkin Yayıncılık.

Hatipoğlu, Z. ve Dündar, G. İ. (2018). “Örgütsel Bağlılık ve İş Tatmini Arasındaki İlişkinin X ve Y Kuşaklarına Göre Farklılıklarının İncelenmesi”, Yorum-Yönetim-Yöntem Uluslararası Yönetim-Ekonomi ve Felsefe Dergisi, 6(2), 43-56.

Hijazi, S., Kasim, A. L. \& Daud, Y. (2016). “Leadership Styles and Their Relationship with the Private University Employees' Job Satisfaction in United Arab Emirates", Journal of Public Administration and Governance, 6(4), 110-124. 
Hoş, C. ve Oksay, A. (2015). “Hemşirelerde Örgütsel Bağlılık İle İş Tatmini İlişkisi”, Süleyman Demirel Üniversitesi İktisadi ve İdari Bilimler Fakültesi Dergisi, 20(4), 1-24.

İraz, R. ve Akgün, Ö. (2011). “Örgütsel Bağlılığın Çalışan Performansı Üzerine Etkilerini Ölçmeye Yönelik Bir Çalışma”, Selçuk Üniversitesi Sosyal Bilimler Meslek Yüksek Okulu Dergisi, 14(1-2), 225-250.

İşler, D. B. ve Özdemir, Ş. (2010). “Hastane İşletmelerinde İçsel Pazarlama Yaklaşımının İş Tatmini ve Örgütsel Bağlılık Üzerine Etkisi: Isparta İli Örneği”, Hacettepe Sağlık İdaresi Dergisi, 13(2), 115-142.

Jabbar, M. N., Hussin, F., Hashmi, M. A. \& Jafri, S. M. I. (2020). “Effect of Administrative Practices on Job Performance: An Empirical Study among Public University Employees in Pakistan", Global Academic Journal of Economics and Business, 1(1), 1-4.

Jafarova, F. ve Sağlam, N. (2018)." Çalışanların İş Tatmini, Örgütsel Bağlılık ve İşten Ayrılma Niyetlerinin Karşılaştırmalı Analizi”, İstanbul Aydın Üniversitesi Dergisi, 10(3), 57-82.

Judge, T. A., Thoresen, C. J., Bono, J. E. \& Patton, G. K. (2001). “The Job Satisfaction-Job Performance Relationship: A Qualitative and Quantitative Review", Psychological Bulletin, 127(3), 376-407.

Kahya, C. (2013). “Örgütsel Sinizm, İş Performansını Etkiler Mi? İş Tatminin Aracılık Etkisi”, Küresel İktisat ve İşletme Çalışmaları Dergisi, 2(3), 34-46.

Kahyaoğlu, M. ve Akca, M. (2020). “Kurumsal İmajın İş Tatminine Etkisinde Duygusal Bağlılığın Rolü: Konaklama İşletmeleri Üzerinde Bir Araştırma", Turizm Akademik Dergisi, 7(1), 225-240.

Kalantari, T., Bahmani, M., Heydari, S. T., Daneshfard, B., Nematollahi, Z. \& Nimrouzi, M. (2018). "Effect of Temperament on Happiness and Job Satisfaction in University Employees", Pakistan Journal of Medical \& Health Sciences, 12(2), 915-917.

Kale, E. \& Aknar, A. (2020). "The Effects of Attributional Style on Job Satisfaction, Job Performance, and Turnover Intention: The Case of Hotel Employees", Anemon Muş Alparslan Üniversitesi Sosyal Bilimler Dergisi, 8(2), 523-531.

Karadirek, G. (2020). “Çalışanların Algıladıkları Örgütsel Desteğin; Motivasyon, İş Tatmini ve Örgütsel Bağlılıkla İlişkisi: Bir Tekstil İşletmesi Örneği”", Nevşehir Hacı Bektaş Veli Üniversitesi SBE Dergisi, 10(1), 203-220.

Karadirek, G. ve Genç, K. Y. (2019). “Bireyci-Toplumcu Kültür Eğiliminin İş Tatmini İle Örgütsel Bağlılık Arasındaki İlişkide Aracılık Rolü: Akademik Personel Üzerinde Bir Uygulama", Asya Studies-Academic Social Studies, (8), 111-121.

Karakoç, A. (2018). “İş Tatmininin Örgütsel Bağlılık ve İş Gören Performansı Üzerindeki Etkisi: Sigorta Acentesi Çalışanları Üzerine Bir Uygulama", Süleyman Demirel Üniversitesi İktisadi ve İdari Bilimler Fakültesi Dergisi, 23(4), 1371-1388.

Kaur, P. (1984). “Job Satisfaction among University Employees”, Indian Journal of Industrial Relations, 20(1), 73-77. 
Kayalar, M. ve Özmutaf, M. (2009). “Bireysel Kariyer Planlamanın İş Tatminine Etkisi: Akademik ve İdari Personel'de Karşılaştırmalı Bir Çalışma", Süleyman Demirel Üniversitesi İktisadi ve İdari Bilimler Fakültesi Dergisi, 14(1), 239-254.

Kırkpınar, S. ve İşcan, Ö. F. (2018). “Liderlik Tarzlarının İş Tatmini ve Örgütsel Bağlılığa Etkileri", Hacettepe Să̆lık İdaresi Dergisi, 22(1), 65-85.

Kirkman, B. L. \& Rosen, B. (1999). “Beyond Self-Management: Antecedents and Consequences of Team Empowerment", The Academy of Management Journal, 42(1), 5874 .

Koca, S. ve Yıldız, S. M. (2018). “Futbol Hakemlerini Strese İten Faktörler, İş Tatmini ve İş Performansı İlişkisinin İncelenmesi", Spor Bilimleri Araştırmaları Dergisi, 3(2), 195-207.

Kohli, A. (1985). "Some Unexplored Supervisory Behaviors and Their Influence on Salespeople's Role Clarity, Specific Self- Esteem, Job Satisfaction, and Motivation", Journal of Marketing Research, 22(4), 424-433.

Konovsky, M. A. \& Cropanzano, R. (1991). “Perceived Fairness of Employee Drug Testing as a Predictor of Employee Attitudes and Job Performance", Journal of Applied Psychology, 76(5), 698-707.

Lamsa, A.-M. \& Savolainen, T. (1999). “The Nature of Managerial Commitment to Strategic Change", Leadership \& Organization Development Journal, 21(6), 297-306.

Locke, E. A. (1969). "What is Job Satisfaction?", Organizational Behavior and Human Performance, 4(4), 309-336.

Love, K. M., Tatman, A. W. \& Chapman, B. P. (2010). “Role Stress, Interrole Conflict, and Job Satisfaction Among University Employees: The Creation and Test of a Model", Journal of Employment Counseling, 47(1), 30-37.

Luthans, F. (2011). Organizational Behavior: An Evidence-Based Approach. Twelfth Edition, New York: The McGraw-Hill Companies Inc.

Malik, M. E., Nawab, S., Naeem, B. \& Danish, R. Q. (2010). "Job Satisfaction and Organizational Commitment of University Teachers in Public Sector of Pakistan", International Journal of Business and Management, 6(6), 17-26.

Marliati, Hamid, N. \& Yusuf, R. M. (2020). “The Impact of Mutation and Organizational Culture on Performance through Job Satisfaction of Hasanuddin University Employees", Hasanuddin Journal of Applied Business and Entrepreneurship, 3(1), 62-72.

Marrow, P. C. \& McElroy, J. C. (1986). “On Assessing Measures of Work Commitment”, Journal of Occupational Behaviour, 7(2), 139-145.

Marrow, P. C. (1983). “Concept Redundancy in Organizational Research: The Case of Work Commitment", Academy of Management Review, 8(3), 486-500.

Matkar, A. (2012). "Cronbach's Alpha Reliability Coefficient for Standard of Customer Services in Maharashtra State Cooperative Bank", The IUP Journal of Bank Management, 11(3), 89-95. 
McCloy, R. A., Campbell, J. P. \& Cudeck, R. (1994). “A Confirmatory Test of a Model of Performance Determinants", Journal of Applied Psychology, 79(4), 493-505.

Mete, E. S. \& Sökmen, A. (2019). “The Mediating Role of Organizational Commitment in the Organizational Justice's Effect on Job Satisfaction and Turnover Intention: A Research on Academic Staff", Gazi İktisat ve İşletme Dergisi, 5(3), 193-205.

Meyer, J. P. \& Allen, N. J. (1991). “A Three-Component Conceptualization of Organizational Commitment", Human Resource Management Review, 1(1), 61-89.

Meyer, J. P., Allen, N. J. \& Smith, C. A. (1993). “Commitment to Organizations and Occupations: Extension and Test of a Three-Component Conceptualization", Journal of Applied Psychology, 78(4), 538-551.

Meyer, J. P., Stanley, D. J., Herscovitch, L. \& Topolnytsky, L. (2002). “Affective, Continuance, and Normative Commitment to the Organization: A Meta-analysis of Antecedents, Correlates and Consequences", Journal of Vocational Behavior, 61(1), 20-52.

Mimaroğlu Özgen, H. ve Özgen, H. (2010). "Psikolojik Sözleşme ve Boyutlarının İş Tatmini, Örgütsel Bağlılık ve İşten Ayrılma Niyetine Etkileri: Tıbbi Satış Temsilcileri Üzerinde Bir Araştırma", Çukurova Üniversitesi Sosyal Bilimler Enstitüsü Dergisi, 19(1), 1-19.

Moazzezi, M., Sattari, S. \& Bablan, A. Z. (2014). “Relationship Between Organizational Justice and Job Performance of Payamenoor University Employees in Ardabil Province", Singaporean Journal of Business Economics, And Management Studies, 2(6), 57-64.

Mowday R. T., Porter L. W. \& Steers R. M. (1982). Employee-Organization Linkages: The Psychology of Commitment, Absenteeism and Turnover. First Edition, New York: Academic Press.

Muchinsky, P. M. (2006). Psychology Applied to Work: An Introduction to Industrial and Organizational Psychology. Eighth Edition, United States of America: Thomson Wadsworth.

Naik, A. R. (2015). “The Relationship between Personality Factors and Organizational Commitment among University Employees", The International Journal of Indian Psychology, 2(4), 175-179.

Nergiz, E. ve Yılmaz, F. (2016). “Çalışanların İş Tatmininin Performanslarına Etkisi: Atatürk Havalimanı Gümrüksüz Satış İşletmesi Örneği", Kastamonu Üniversitesi İktisadi ve İdari Bilimler Fakültesi Dergisi, 14(4), 50-79.

Newstrom, J. W. (2007). Organizational Behavior: Human Behavior at Work. Twelfth Edition, New York: The McGraw-Hill Companies Inc.

Nwani, B. E. \& Udechukwu D. C. (2014). "Influence of Staff Type and Job Status on Organizational Commitment of Ebonyi State University Workers", ANSU Journal of Arts and Social Sciences, 2(2), 23-32.

O'Reilly, C. A. (1989). "Corporations, Culture and Commitment: Motivation and Social Control in Organizations", California Management Review, 31(4), 9-25. 
Ocak, M., Güler, M. ve Basım, H. N. (2016). “Psikolojik Sermayenin Örgütsel Bağlılık ve İş Tatmini Tutumları Üzerine Etkisi: Bosnalı Öğretmenler Üzerine Bir Araştırma", Çankırı Karatekin Üniversitesi İktisadi ve İdari Bilimler Fakültesi Dergisi, 6(1), 113-130.

Özdamar, K. (2017). Eğitim, Sağllk ve Davranış Bilimlerinde Ölçek ve Test Geliştirme Yapısal Eşitlik Modellemesi: IBM SPSS, IBM SPSS AMOS ve MINITAB Uygulamalı. 2. Baskı, Eskişehir: Nisan Kitabevi Yayıncılık.

Özdemir, H., Dağdeviren, A., Göker, G. ve Özdemir, S. N. (2017). “Otel Çalışanlarının İş Tatmini ve Örgütsel Bağlllık Düzeyleri Üzerine Bir Araştırma”, Güncel Turizm Araştırmaları Dergisi, 1(2), 114-123.

Özkan, U. D., Ertuğral, S. M., Tekeli, H. N. ve Akova, O. (2019). “Otel İşletmelerinde Çalışanların İş Tatmini Algılarının Örgütsel Bağlılıkları Üzerindeki Etkisi”, International Journal Entrepreneurship and Management Inquiries Dergisi, 3(4), 146-164.

Özkutlu, H. (2008). “Örgüte Duygusal, Devamlılık ve Normatif Bağlılık İle İş Performansı Arasındaki İlişkinin İncelenmesi", İstanbul Üniversitesi İşletme Fakültesi Dergisi, 37(2), 79-97.

Özmen, M. ve Kahraman, Ü. G. (2017). “Aile İşletmelerinde Çalışanların İş Tatmini ve Örgütsel Bağlılık Düzeyleri Arasındaki İlişkiye Yönelik Bir Araştırma", Süleyman Demirel Üniversitesi İktisadi ve İdari Bilimler Fakültesi Dergisi, 22(1), 85-93.

Özpehlivan, M. (2019). “The Relationship Among Organizational Communication, Job Satisfaction, Individual Performance and Organizational Commitment in Different Cultures", Bilecik Şeyh Edebali Üniversitesi Sosyal Bilimler Enstitüsü Dergisi, 4(1), 32-54.

Pitaloka, E. \& Sofia, I. P. (2014). “The Affect of Work Environment, Job Satisfaction, Organization Commitment on OCB of Internal Auditors", International Journal of Business, Economics and Law, 5(2), 10-18.

Poyraz, K. ve Kama, B. (2008). “Algılanan İş Güvencesinin, İş Tatmini, Örgütsel Bağlılık ve İşten Ayrılma Niyeti Üzerindeki Etkilerinin İncelenmesi", Süleyman Demirel Üniversitesi İktisadi ve İdari Bilimler Fakültesi Dergisi, 13(2), 143-164.

Robbins, S. P. (1990). Organization Theory: Structure, Design and Applications. Third Edition, New Jersey: Prentice-Hall Inc.

Robson, N. I., Udo, A. A. \& Efiok, J. N. (2016). “Perceived Career Development Support and Organizational Commitment among Academic and Non-Academic University Employees", Scholars Journal of Economics, Business and Management, 3(3), 92-99.

Roethlisberger, F. J. \& Dickson, W. J. (2003). The Early Sociology of Management and Organizations: Management and the Worker (Volume V). Third Edition, New York: Routledge-Taylor \& Francis Group.

Schaffer, R. H. (1953). "Job Satisfaction as Related to Need Satisfaction in Work", Psychological Monographs: General and Applied, 67(14), 1-29.

Scherer, R. F., Luther, D. C., Wiebe, F. A. \& Adams, J. S. (1988). “Dimensionality of Coping: Factor Stability Using the Ways of Coping Questionnaire", Psychological Reports, 62(3), 763-770. 
Schneider, B. \& Snyder, R. A. (1975). "Some Relationships Between Job Satisfaction and Organization Climate", Journal of Applied Psychology, 60(3), 318-328.

Schroder, R. (2008). "Job Satisfaction of Employees at a Christian University", Journal of Research on Christian Education, 17(2), 225-246.

Schumacker, R. E. \& Lomax, R. G. (2004). A Beginner's Guide to Structural Equation Modeling. Second Edition, Mahwah: Lawrence Erlbaum Associates, Inc.

Sigler, T. H. \& Pearson, C. M. (2000). "Creating an Empowering Culture: Examining the Relationship Between Organizational Culture and Perceptions of Empowerment", Journal of Quality Management, 5(1), 27-52.

Smeenk, S., Teelken, C., Eisinga, R. \& Doorewaard, H. (2009). "Managerialism, Organizational Commitment, and Quality of Job Performances among European University Employees", Research in Higher Education, 50(6), 589-607.

Smeenk, S., Teelken, C., Eisinga, R. \& Dooreward, H. (2008). “An International Comparison of the Effects of HRM Practices and Organizational Commitment on Quality of Job Performances among European University Employees", Higher Education Policy, 21(3), 323-344.

Smith, P. C. \& Goddard, M. (2002). "Performance Management and Operational Research: A Marriage Made in Heaven?", The Journal of the Operational Research Society, 53(3), 247255.

Sökmen, A. ve Bıyık, Y. (2016). “Örgütsel Bağlılık, Örgütsel Özdeşleşme, Kişi-Örgüt Uyumu ve İş Tatmini İlişkisi: Bilişim Uzmanlarına Yönelik Bir Araştırma”, Bilişim Teknolojileri Dergisi, 9(2), 221-227.

Spector, P. E. (1999). Industrial and Organizational Psychology: Research and Practice. Second Edition, New York: John Wiley \& Sons Inc.

Swaidan, R. \& Adwan, S. H. A. (2019). "The Degree of the Influence of the Internal Environment on the Organizational Commitment of the Staff of Al-Istiqlal University", Journal of University of Babylon for Pure and Applied Sciences, 27(5), 102-127.

Şahin, S. ve Çankır, B. (2018). “İş Tatmininin İş Performansına Etkisinde Çalışmaya Tutkunluğun Aracı Rolü: Satış ve Pazarlama Sektöründe Bir Araştırma”, Uluslararası İktisadi ve İdari İncelemeler Dergisi, (17. UİK Özel Say1s1), 389-402.

Şen, C. ve Mert, İ. S. (2019). “Psikolojik Sermayenin İş Tatmini, Örgütsel Bağlılık ve Sinizm Üzerindeki Etkisi", Anemon Muş Alparslan Üniversitesi Sosyal Bilimler Dergisi, 7(4), 921.

Şeşen, H. ve Kahraman, Ç. A. (2014). "İş Arkadaşlarının Sosyal Kaytarmasının, Bireyin İş Tatmini, Örgütsel Bağlllık ve Kendi Kaytarma Davranışlarına Etkisi", İş ve İnsan Dergisi, 1(1), 43-51.

Tanrıöğen, A. (2012). Bilimsel Araştırma Yöntemleri. 3. Baskı, Ankara; Anı Yayıncılık. 
Tantekin Çelik, G. ve Laptalı Oral, E. (2013). “Türk İnşaat Sektörü Çalışanlarının Kişilik Özelliklerinin, Örgütsel Bağlılık ve İş Tatmini ile İlişkisi”, Çukurova Üniversitesi Mühendislik Mimarlık Fakültesi Dergisi, 28(2), 15-26.

Tekin, B. ve Deniz, B. (2019). “Muhasebe Meslek Mensuplarının İş Stresi, İş Performansı ve İş Tatmini Düzeyleri Üzerinde Kontrol Odağı Etkili Bir Faktör Mü?”, Muhasebe ve Finansman Dergisi, (84), 65-94.

Tomer, A. \& Pugesek, B. H. (2003). Guidelines for The Implementation and Publication of Structural Equation Models. In Bruce H. Pugesek, Adriantomer \& Alexander Von Eye (Ed.), Structural Equation Modeling: Applications in Ecological and Evolutionary Biology. First Edition, United Kingdom-New York: Cambridge University Press.

Tunay, N. (2019). “Personel Güçlendirmenin Çalışanların İş Tatmini, Performansı ve Örgütsel Bağlılığına Etkileri: Türk Sigorta Sektörü Örneği", Maliye ve Finans Yazıları, (112), 241-258.

Tuzcu, A. (2014). “The Impact of Corporate Social Responsibility Perception on The Job Satisfaction and Organizational Commitment", Çankırı Karatekin University Journal of The Faculty of Economics and Administrative Sciences, 4(1), 185-202.

Uludağ, G. (2018). “Örgütsel Bağlılık İle İşgören Performansı İlişkisini İncelemeye Yönelik Bir Alan Araştırması”, Bitlis Eren Üniversitesi Sosyal Bilimler Enstitüsü Dergisi, 7(1), 171-193.

Ural, A. ve Kılıç, İ. (2013). Bilimsel Araştırma Süreci ve SPSS ile Veri Analizi. 4. Baskı, Ankara: Detay Yayıncilık.

Viswesvaran, C. \& Ones, D. S. (2000). "Perspectives on Models of Job Performance", International Journal of Selection and Assessment, 8(4), 216-226.

Weiss, D. J., Dawis, R. V., England, G. W. \& Lofquist, L. H. (1967). Manual for the Minnesota Satisfaction Questionnaire. Minneapolis: Minnesota Studies in Vocational Rehabilitation (Volume 22).

Wernimont, P. F. (1966). "Intrinsic and Extrinsic Factors in Job Satisfaction", Journal of Applied Psychology, 50(1), 41-50.

Wiener, Y. \& Vardi, Y. (1980). "Relationships Between Job, Organization and Career Commitments and Work Outcomes-An Integrative Approach", Organizational Behavior and Human Performance, 26(1), 81-96.

Wiener, Y. (1982). "Commitment in Organizations: A Normative View", The Academy of Management Review, 7(3), 418-428.

Yalçınsoy, A. ve Aksoy, C. (2019). “Örgütsel Bağlılık, İş Tatmini ve İşkoliklik Arasındaki İlişki", Avrasya Sosyal ve Ekonomi Araştırmaları Dergisi, 6(1), 365-375.

Yıldırım, H., Albayrak, A. S., Gümüş, M. ve Akalın, T. C. (2011). “Yüzme Hakemlerinde Örgütsel Bağlılık İle İş Tatmini Arasındaki İlişkinin Kanonik Korelasyon Analizi İle İncelenmesi", Uluslararası Yönetim İktisat ve İşletme Dergisi, 7(13), 163-186. 
Yolaç, G. (2008). “Satış Elemanlarının Müşteri Yönelimi İle İş Tatmini, Örgütsel Bağl1lı̆̆ ve Demografik Özellikleri Arasındaki İlişkinin Belirlenmesine Yönelik Bir Araştırma", Öneri, 8(29), 119-125.

Yumuşak, S., Özafşarlıoğlu, S. ve Yıldız, H. (2013). “İş Tatmini İle Örgütsel Bağlılık Arasındaki İlişkinin İncelenmesi: Uşak Tekstil Sektöründe Bir Uygulama", Ege Stratejik Araştırmalar Dergisi, 4(2), 56-79.

Yüksel, Ö. F. ve Düşükcan, M. (2019). “Etik İklim Algısının İş Görenlerin İş Tatmini Düzeyleri ve Örgütsel Bağlılık Düzeyleri Üzerine Etkisi: ARÇELIKK A.Ş. Adana ve Elazığ Bölge Yöneticiliklerinde Uygulama", Selçuk Üniversitesi Sosyal Bilimler Meslek Yüksekokulu Dergisi, 22(1), 53-65.

Zeer, I. A., Alkhatib, A. A. \& Alshrouf, M. (2020). “Organizational Commitment of University Employees from the Social Factors Perspective", International Journal of Advanced Science and Technology, 29(8), 2816-2824.

Zeynel, E. ve Çarıkçı, İ. H. (2015). “Mesleki Motivasyonun, İş Tatmini ve Örgütsel Bağlılık Üzerine Etkisi: Akademisyenler Üzerine Görgül Bir Araştırma”, Süleyman Demirel Üniversitesi İktisadi ve İdari Bilimler Fakültesi Dergisi, 20(3), 217-248. 